\title{
ACNP.-68505-D (Suppl)
}

LACBWR Operating Manual

Volume VII, Waste Collection and Treatment

5.4.3 Retention Tank IB Recirculation .......... 5-9

5.4.4 Retention Tank 1B Transfer to 3000- or 4500-Gal

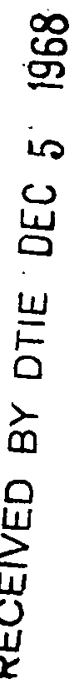

Storage Tanks .............. . . 5-10

5.4.5 Retention Tank IB Transfer to Evaporator Feed Tank .. .. 5-12

5.4.6 Retention Tank IB Transfer to the Radwaste Ion Exchanger . 5-13

5.4.7 Retention Tank 1B Discharge to Standpipe ... . . . . 5-15

5.4.8 Retention Tank IB Recirćulation Through Portable

Demineralizer .................... . . . . 5-16

5.4.9 3000-Gal Storage Tank Recirculation ... . . . 5-17

5.4.10 3000-Gal Waste Water Storage Tank Transfer to

Evaporator Feed Tank . . . . . . . . . . 5-18

5.4.11 3000-Gal Storage Tank Transfer to Radwaste Ion

Exchanger .............. . . 5-20

5.4.12 3000-Gal Storage Tank Discharge to Standpipe . . . . 5-21

5.4.13 Waste Treatment Building, Gas Storage Vault, and the

Turbine Building Sump Pumps Discharge to Retention

Tanks .................. . . . 5-23

5.4.14 4500-Gal Storage Tank Recirculation . . . . . . . 5-24

5.4.15 4500-Gal Storage Tank Transfer to Evaporator Feed Tank. 。 5-25

5.4.16 4500-Gal Storage Tank Transfer to Radwaste Ion

5.4.17 4500-Gal Storage Tank Discharge to Standpipe . . . . 5 5-28

5.4.18 Change Room Drain Tank Recirculation . . . . . . . . 5-30

5.4.19 Change Room Drain Tank Discharge to Standpipe .. . . . 5-31

5.4 .20 Change Room Drain Tank Transfer to Storage Tanks .. . 5-33

5.4.21 Evaporator Feed Tank Recirculation Through Eductor for

Chemical Addition ... . . ........ 5-33

5.4.22 Evaporator Feed Tark Discharge to the Evaporator . .. . . 5-34

5.4.23 Water Collection Tank Recirculation Through Radwaste

5.4.24 Water Collection Tank Discharge to Main Condenser $5-41$

5.4.25 Water Collection Tank Discharge to. Standpipe . . . . . 5-42

5.4.26 : Concentrated Waste Tank Mixing and Recirculation .. . . 5-43

5.4.27 Preparation of Spent Resin Tank for Receiving Spent

Resins from the Primary Purification System, Radwaste

Ion Exchanger, and Condensate Demineralizers _. .. . . . 5-44

5.4 .28

Radwaske lon Exchanger Spent Resin Transfer to Spent

Resin Tank .......... . . . . 5-45

5.4.2.9 Radwaste lon Exchanger New Resin Loading . . . . . 5-46

5.4.30 Evaporator Bottoms Discharge to Drumming Station . . . 5-48

5.4.31 Concentrated Waste Tank Discharge to Drumming Station . 5-49

5.4.32 Spent Resin Discharge to Drumming Station . . . . . 5-50

5.4.33 Concentrated Waste Drumming . . . . . . . . 5-51

5.4.34 Waste Water System Flushing . . . . . . . . . . 5-54

5.4.35 Slurry Transfer to Spent Resin Tank from Waste Water

Storage Tanks . . . . . . . . . . . 5-56 


\section{DISCLAIMER}

This report was prepared as an account of work sponsored by an agency of the United States Government. Neither the United States Government nor any agency Thereof, nor any of their employees, makes any warranty, express or implied, or assumes any legal liability or responsibility for the accuracy, completeness, or usefulness of any information, apparatus, product, or process disclosed, or represents that its use would not infringe privately owned rights. Reference herein to any specific commercial product, process, or service by trade name, trademark, manufacturer, or otherwise does not necessarily constitute or imply its endorsement, recommendation, or favoring by the United States Government or any agency thereof. The views and opinions of authors expressed herein do not necessarily state or reflect those of the United States Government or any agency thereof. 


\section{DISCLAIMER}

Portions of this document may be illegible in electronic image products. Images are produced from the best available original document. 
LACBWR Operating Manual

Volume VII, Waste Collection and Treatment
April, 1968

Revised October, 1968

\section{WASTE TRANSFER TREATMENT PROCEDURES}

\subsection{PREREQUISITES AND INITIAL CONDITIONS}

1. Control power at the Waste Disposal Building MCC, Reactor Building MCC, and/or the Turbine Building MCC is available for operation of the necessary pumps.

2. All pumps in the system have been vented, and the oil level has been checked.

3. All sump pumps local control stations are in the AUTO position.

4. All required instruments have been checked and found to be satisfactory.

5. All relief valve gags have been removed.

6. Instrument air is in operation.

7. The reactor shift supervisor and the health physicist have been notified of the specific operations to be performed.

8. The latest approved procedures for the operations to be performed will be reviewed prior to commencing the operations, and they will be utilized to perform the operations.

9. Complete Valve Checklist VII - 5.1, LIQUID WASTE COLLECTION AND TREATMENT VALVE CHECKLIST.

\subsection{HAZARDS AND PRECAUTIONS}

1. The contents of each tank to be sampled and analyzed is to be thoroughly mixed by recirculation or air sparging prior to sampling to assure a representative sample.

2. The contents of all tanks must be kept strictly isolated from further additions after sampling of contents for analysis is made in order to assure that the results of analysis are a truly representative analysis of the waste quality. This is particularly applicable when the contents of any tank are being pumped to the river .

3. The Liquid and Service Water Monitor and the Turbine Cond. Cooling Water Monitor are continuously monitored while discharging to the river.

4: The temperature of pipe lines that contain concentrated wastes must be maintained at $150 \mathrm{~F}$ or above to preclude the lines becoming plugged. 
LACBWR Operating Manual

Volume V.II, Waste Collection and Treatment
April, 1968

Revised October, 1968

5. The handling of waste batches greater than $800 \mathrm{gal}$ must be monitored closely to preclude the overflowing of the waste process tanks.

6. The radioactivity of wastes to be drummed must be accurately known, and the allowable volume of concentrated waste allowable in each drum must be established, prior to initiation of the drumming operation.

7. The amount of sluice water used in transferring depleted resins to the spent resin tank must be controlled so that the spent resin tank does not overflow.

8. The contents of the concentrated waste tank must be checked to assure that cake formation does not occur. The air/steam sparger is to be used as required.

\subsection{GENERAL PROCEDURES}

\subsubsection{Disposal of Liquid Waste from Storage or Retention Tanks}

After a tank contents are recirculated, a sample is withdrawn from the tank and is checked for radioactivity level. If the radioactivity level is low enough to permit direct discharge of tank contents to the river without processing, further analysis is not necessary. If a high radioactivity level precludes direct disposal, the sample is analyzed for conductivity. A highly radioactive sample with a conductivity less than or equal to $20 \mu \mathrm{mho} / \mathrm{cm}$ will be processed through the radwaste ion exchanger. A sample with a conductivity above 20 $\mu \mathrm{mho} / \mathrm{cm}$ will be transferred to the evaporator feed tank, and the waste. will be concentrated at the evaporator prior to its disposal as solids. Care must be taken so that only approximately $800 \mathrm{gal}$ are processed at a time; otherwise, the water collection tank or the evaporator feed tank will be overfilled.

\subsubsection{Direct Discharge to the River}

After analysis of the collected batch of waste has determined that the radioactive level is such that direct discharge is allowed, the allowable rate of discharge is determined by the health physicist. A "Liquid Waste Batch Form" (Fig.5.4-9) must be filled out and signed by a Health and Safety representative and the Operations Shift Supervisor on duty prior to discharging any liquid waste to the river.

The total flow indicator is read and recorded. The radiation monitor system in the service water discharge line is checked for proper operation. The normally-locked globe valve in the discharge line is gradually opened until the correct flow rate for proper dilution is obtained.

After the collecting tank has been emptied, the liquid waste monitor lines are flushed, then the globe valve in the discharge line to the river is locked closed. The indicator on the flow totalizer is read and recorded. The "Liquid Waste Batch Form" is then completed, and returned to Health and Safety for record purpose. 


\subsubsection{Evaporation Process}

The contents of the evaporator feed tank are recirculated to obtain a homogeneous mixture. The contents of the feed tank are then sampled and the $\mathrm{pH}$ determined. The source of the waste is noted. The proper amount of additive $(\mathrm{pH}$ control and/or defoaming agents) is added to the chemical mixing tank. The contents of the chemical mixing tank are drawn into the circulating waste solution through the eductor. The contents of the evaporator feed tank are periodically checked until the $\mathrm{pH}$ is between 6 and 8 . The evaporator feed pump is lined up to the evaporatorinilet line and is operated until the evaporator feed flow control valve automatically positions itself at not full open. Steam is permitted to flow through the shell side of the evaporator, and the evaporator pump is started again. The steam flow will balance itself to maintain a pressure of $15 \mathrm{psig}$ in the evaporator. The evaporator feed will automatically regulate itself in order to maintain the correct level of bottoms in the evaporator.

The vapor generated in the tube side of the evaporator passes out of the evaporator through a steel-wool-packed demister to the evaporator condenser, and it is then discharged to the water collection tank.

The flow of service water is adjusted through the tube side of the evaporator condenser until the condensed vapor is cooled to at least 120.F.

The evaporator demister is backflushed after completion of each batch to clean the demister of any entrained particles. The demister drains to the evaporator bottoms section. When the evaporator bottoms are concentrated to the desired weight percent (as calculated by knowledge of feed concentration and quantity processed), the evaporator feed pump is stopped. The steam supply is now manually opened and closed to keep the bottoms temperature at about 212.F.

During the course of evaporation, the following items are periodically monitored:

.1. Feed flow control valve is operating correctly.

2. Pressure of the steam is being maintained at 15 psig.

3. Pressure of the evaporator vapor does not exceed 5 psig.

4. The Hi-foam switch has not activated.

See Sec. 5.3.5 for the general operations performed to dump evaporator bottoms.

\subsubsection{Processing of Water in Water Collection Tank}

The contents of the water collection tank are sampled for radioactivity, conductivity, $\mathrm{pH}$, and chlorides. If there is room in the main condensate water surge tank, and if the analyses of the above items prove satisfactory, the water in the water collection 
tank is pumped to the main condenser hotwell by means of the process waste transfer pump. The excess water introduced to the hotwell is transferred by the condensate pump to the main condensate water surge tank.

If there is no available storage space in the main condensate water surge tank, and if the radioactivity level meets the 10 CFR 20 standards, the water is pumped to the river.

If the reclaimed water in the water collection tank has high radioactivity, so that it cannot be dumped to the river or stored, it must be further processed through the radwaste ion exchanger.

\subsubsection{Transfer of Evaporator Bottoms}

The evaporator bottoms are transferred by gravity to either the drumming station or to the concentrated waste storage tank. Normally, the bottoms will be transferred directly to the drumming station to eliminate the problems associated with storing a concentrated solution (problems such as solidification, having to heat and having to clean the concentrated waste tank, and its discharge lines after its use).

If the drumming station is not available, and if continued use of the evaporator is required, the heating coils on the line to the concentrated waste tank are energized. The heating coils will keep the pipe at a minimum of $150 \mathrm{~F}$. The extended stem plug valve in the line to the storage tank is opened, and the bottoms are drained into the tank. After the evaporator bottoms have completed draining into the concentrated waste tank, the liquid demineralizer pump is turned on to descale the tubes and to flush out the bottoms pipe to the storage tank. The bottoms plug valve is then shut; the evaporator level is retumed to operating condition, and evaporation is continued as discussed in Sec. 5.3.3.

The steam sparger to the concentrated waste storage tank is operated as necessary to keep the stored concentrated waste in a fluid condition.

\subsubsection{Drumming of Concentrated Waste}

The basic container will always be a 55-gal drum. Normally, the liquid waste will be mixed with cement and absorbent with in the empty 55-gal drum. However, if the radiation levels of the liquid waste are such that the self-shielding of the mixture is not sufficient to meet the requirements of 10 CFR 20, there will be a cement shielding poured into the annulus formed by placing a 35-gal drum within the 55-gal drum.

The empty drums are brought into the waste disposal building on the ground floor. Before being. lowered to the basement, $48 \mathrm{lb}$ of Vermiculite are added into the drum. 
Hoists are located in the overhead of the grade level floor so that the drums can be moved from the doors to a position over the hatch, and then lowered into and raised out of the basement. The drums, after being charged with cement and concentrated waste, will weigh approximately $650 \mathrm{lb}$.

The cement block box is of such height that any splashing about that may occur during the filling and mixing of the waste will be contained. The drum is clamped in position on the dolly, by a screw jack having an extended handle that protrudes through the concrete block box. The dolly is then positioned beneath the mixer by manipulating the jack handle.

The machine is then lowered to near the bottom of the drum. Liquid waste is either drained into the drum from the evaporator or is pumped into the drum from the concentrated waste tank. If the waste is pumped in from the concentrated waste tank, the volume is controlled by setting the revolution counter on the shaft of the positive displacement pump. Two bags of cement are added in steps to the mixture of Vermiculite and liquid waste.

The machine is now raised and lowered on its rack so that the mixer blade rotates at all elevations of the wet cement until a homogeneous mass is obtained.

After checks by the health physicist to insure proper radioactivity levels, the barrel is lifted from the box and is placed on the grade level floor, where it is allowed to stand until the cement sets. In the event that there is a puddle of water remaining on the surface of the cement after it has set, dry cement is sprinkled on the top until all the moisture is absorbed.

After final checks and labeling by the health physicist, the top of the barrel is put on and welded in place. The capped barrel is then removed for outside storage in a properly controlled area.

Certain modifications to the above procedure may be made as circumstances dictate:

When any of the evaporator bottoms are too radioactive for self-shielding to be adequate, a 35-ga' drum will be placed on a cement block within a 55-gal drum. The resulting annulus will be filled with wet cement that has been mixed separately in a pan; the cement will be allowed to set in the drum. These combination drums may be prepared in advance for more efficient operation.

A smaller-sized mixing blade cross-bar will be used to fit the 35-gal drum; and proportionally less amounts of cement, absorbent, and concentrated waste will be used. 
LACBWR Operating Manual

Volume VII, Waste Collection and Treatment

April, 1968

Revised October, 1968

\subsubsection{Cleaning of Pipe After Drumming Operation}

After the drumming of a batch of evaporator bottoms, or at the end of a day, the pipe lines handling the concentrated waste are flushed into a 55-gal drum so that the pipe lines will not become plugged with caked concentrated waste.

The electric heaters on the concentrated waste lines are then secured. The drumming station concrete block box interior is washed down with L.P. service water supplied through a hose connection located on the exterior of the drumming station.

\subsubsection{Collection and Drumming of Spent Resin}

Depleted resin is sluiced to the spent resin tank from the radwaste ion exchanger, the primary purification system cation exchanger, and the primary purification mixed bed ion exchanger. Condensate demineralizer resin that has become fouled or otherwise cannot be regenerated is also sluiced to the spent resin tank. The IB waste water transfer pump is used to sluice to the spent resin tank. the resin lines. and particulate matter that accumulates in the waste water tanks as a result of backwashing condensate demineralizers.

The spent resin storage tank is sized to accept one complete condensate demineralizer charge of resin and its accompanying sluice water.

The resins can be stored in the tank until short-lived decay has occurred.

The drums are prepared and landed at the drumming station in the same manner as described for the drumming of evaporator bottoms in Sec. 5.3.6.

The spent resin tank has sufficient sluice water within it to carry out the contained resin. The spent resin is transferred by gravity to the drumming station, and the resin is charged to the drum in the same manner as the evaporator bottoms.

Prior to actual drumming, the health physicist has calculated the quantity of resin to be added to each drum by knowledge of the resin radioactivity and the effects of concrete shielding in the drum.

Depending on the economics of the specific situation, it may be prudent to drum in a 35 -gal drum that has been placed inside a 55-gal drum and which has had the annulus filled with cement.

The resin sluice lines are then cleaned by flushing into the spent resin tank for $10 \mathrm{sec}$. The remaining lines are then flushed to a 55-gal drum placed in the drumming station.

\subsection{OPERATING PROCEDURES}

For general information, Figs. 5.4-1 through 5.4-9 have been included at the end of Sec. 5, as have appropriate checklists. 
LACBWR Operating Manual

Volume VII, Waste Collection and Treatment
April, 1968

Revised October, 1968

\subsubsection{Retention Tank IA Transfer to Retention Tank 1B}

The Retention Tank IA receives waste water from all the reactor building floor drains and cannot be isolated. Therefore, its contents are normally transferred to Retention Tank 1B where they are circulated, sampled, and disposed of .

\section{Prerequisites}

1. The reactor building section of the Liquid Waste Collection and Treatment Valve Checklist has been completed.

2. The retention tanks transfer pump is ready for operation.

Procedure

1. Determine that there is sufficient capacity in Retention Tank IB for receiving the water from Retention Tank IA by observing the water level in each tank and by using the tank capacity curves. (Fig. 5.4-3)

2. Open the following valves:

54-24-012, Ret. Tank IA Outlet

54-24-143, Ret. Tank 1B Recirculation

54-24-014, Ret. Tanks Transfer Pump Discharge

3. Place the Retention Tank IA or IB pump cutoff selector switch in the IA position.

4. Start the retention tanks transfer pump by depressing the START button at the local pump control station. Observe that the pump is operating satisfactorily.

5. When the desired volume of water has been transferred, stop the pump by depressing the STOP button at the local pump control station, or by allowing the pump to stop automatically when the level in the retention tank drops to 6 in.

6. After transfer of the water is completed, return the system to normal by closing the valves which were opened in step 2 above.

\section{5:4.2 . Retention Tank 1A Transfer to 3000- or 4500-Gal Storage Tanks}

Retention Tank IA is normally transferred to Retention Tank IB for disposal. However, during abnormal conditions, tank IA can be transferred to either the 3000- or 4500-gal storage tank. Samples are normally taken and analyzed for radioactivity prior to transfer to prevent inadvertent dilution of any potentially highly-contaminated source of 
water which may be in the process of being collected for concentration in the liquid waste evaporator.

\section{Prerequisites}

1. The reactor building and the tunnel and waste water storage area sections of the Waste Collection and Treatment Valve Checklist have been completed.

2. The retention tanks transfer pump is ready for operation.

\section{Procedure}

1. Determine the volume of water to be transferred and the available capacity of the tank which is to receive the waste water by observing the level in each tank and by using the tank capacity curves. (Figs, 5.4-3 and 5.4-4)

2. Open the following valves:

54-24-012, Ret. Tank 1A Outlet

54-24-014, Ret. Tanks Transfer Pump Discharge

*54-24-017, Ret. Tanks Discharge to River or Waste Water Storage Tank

*54-24-025, IA Pump Discharge to River/Retention Tanks

Alternate: If IA Waste Transfer Pump is in use, then: open *54-24-173, 1B Pump Discharge to Ring/Retention Tank, instead of 54-24-025.

Note: When the alternate path is selected, then all alternate valves in the entire procedure must be used.

3. Place the local Retention Tank IA or IB pump cutoff selector switch in the IA position.

4. Open valve 54-25-006, Liquid Waste Containment Isolation, by depressing the OPEN button at the local valve control station.

5. If transferring to the 4500-gal storage tank, open valve 54-24-029, IA Recirc. and Inlet to 4500 -gal tank. If transferring to the 3000 -gal storage tank, open valve 54-24-030, IA Recirc. and Inlet to 3000-gal tank.

Alternate: If the alternate path was selected in step 2 above, then, if transferring to the 4500 -gal storage tank, open valve $54-24-175,1 \mathrm{~B}$ recirc, and inlet to 4500 -gal tank. If transferring to the 3000gal storage tank, open 54-24-174, 1B recirc. and inlet to 3000gal tank.

*denotes locked valve 
6. Start the retention tanks transfer pump by depressing the START button at the local pump control station. Observe that the pump is operating satisfactorily.

7. When the desired volume of water has been transferred, stop the pump by depressing the STOP button at the local pump control station, or from the remote station in the waste treatment building, or by allowing the pump to stop automatically when the level in the retention tank drops to $6 \mathrm{in}$.

8. Return the system to normal by closing the following valves:

*54-24-025, IA Discharge to River/Retention

54-24-030, IA Recirc. and Inlet to 3000-Gal Tank

54-24-012, Ret. Tank 1A Outlet

54-24-014, Ret. Tanks Transfer Pump Discharge

54-25-006, Liquid Waste Containment Isolation

*54-24-017, Ret. Tank Discharge to River or Waste Water Storage Tanks

and by opening valve:

54-24-029, IA Recirc. and Inlet to 4500-Gal Tank.

Alternate: Close valves:

54-24-173, 1B Discharge to River/Retention

54-24-174, IB Recirc. and Inlet to 3000-Gal Tank

54-24-175, IB Recirc. and Inlet to 4500-Gal Tank

\subsubsection{Retention Tank 1B Recirculation}

The retention tank is isolated from the remainder of the system in order to assure that the sample of the contents will be representative and will not be altered by possible addition of liquid waste. The tank contents are recirculated for at least one volume change to obtain a homogeneous mixture. After the sample has been withdrawn, recirculation is continued until permission for disposal has been obtained.

Prerequisites

1. The reactor building section of the Liquid Waste Collection and Treatment Valve Checklist has been completed.

2. The retention tanks transfer pump is ready for operation.

*denotes locked valve 
LACBWR Operating Manual

April, 1968

Volume VII, Waste Collection and Treatment

Revised October, 1968

Procedure

1. Isolate Retention Tank IB by opening valve 54-24-010, Ret. Tank IA Inlet, and closing valve 54-24-011, Ret. Tank IB Inlet.

2. Determine the number of gallons of water in the tank by observing the local level indicator and by using the tank capacity curve. (Fig. 5.4-3)

3. Divide the total number of gallons of water in the tank by the pump capacity $(90 \mathrm{gpm})$ to determine the minimum time for recirculation before withdrawing the sample.

4. Open valves 54-24-013, Ret. Tank IB Outlet, 54-24-143, Ret. Tank IB Recirculation, and 54-24-014, Ret. Tank Transfer Pump Discharge.

5. Start the retention tanks transfer pump by depressing the START button of the local pump control station. Let the contents recirculate for at least the number of minutes determined in steps 2 and 3 before withdrawing sample.

6. Withdraw the sample from the pump discharge while the system is recirculating by opening valve 54-23-046, Ret. Tanks Pump Vent and Sample.

7. After sample has been analyzed by health physics, proceed to appropriate pro= cedure for disposal.

\subsubsection{Retention Tank 1B Transfer to 3000 - or 4500-Gal Storage Tanks}

The retention tank IB contents are normally sampled and disposed of to the river via the main condenser circulating water system. If additional storage is required, the contents can be transferred to either the 3000 - or 4500 -gal storage tank. Samples of the tanks are normally taken and analyzed for activity prior to transfer to prevent inadvertent dilution of a potentially highly contaminated source of water which may be in the process of being collected for concentration in the Liquid Waste Evaporator.

\section{Prerequisites}

1. The reactor building and the tunnel and waste water storage tank area sections of the Liquid Waste Collection and Treatment Valve Checklist have been completed.

2. The retention tanks transfer pump is ready for operation.

Procedure

1. Determine the number of gallons of water to be transferred and the capacity available in the tank which is to receive the waste water by observing the level in each tank and using the tank capacity curves. (Figs. 5.4-3 and 5.4-4) 
NOTE: At least 500-gal capacity should be reserved in storage tanks for the building sump pumps and floor drains, etc.

2. Open the following valves:

54-24-013, Ret. Tank IB Outlet

54-24-014, Ret. Tanks Transfer Pump Discharge

*54-24-017, Ret. Tanks Discharge to River or Waste Water Storage Tanks

*54-24-025, Storage Tanks Discharge to River

Alternate: If IA waste transfer pump is in use, then: open *54-24-173, IB Pump Discharge to River/Retention Tanks, instead of 54-24-025.

NOTE: When the alternate path is selected, then all the alternate valves in the entire procedure must be used.

3. Place the local Retention Tank IA or IB pump cutoff selector switch in the IB position.

4. Open valve 54-25-006, Liquid Waste Containment Isolation, by depressing the OPEN button at the local valve control station.

5. If transferring to the 4500-gal storage tank, open valve 54-24-029, IA Recirc. and Inlet to 4500-Gal Tank. If transferring to the 3000-gal storage tank, open valve 54-24-030, IA Recirc. and Inlet to 3000-Gal Tank.

Alternate: If the alternate path was selected in step 2above, then: if transferring to the $4500-\mathrm{gal}$ storage tank, open 54-24-175, .1B Recirc. and Inlet to $4500-\mathrm{gal}$ tank. If transferring to the $3000 \mathrm{-gal}$ storage tank, open 54-24-174, IB Recirc, and Inlet to 4500-gal tank.

6. Start the retention tanks transfer pump by depressing the START button at the local pump control station. Observe that the pump is operating satisfactorily.

7. When the desired amount of water has been transferred, stop the pump by depressing the STOP button at the local pump control station, or from the remote station in the waste treatment building, or by allowing the pump to stop automatically when the level in the retention tank drops to 6 in.

8. Return the system to normal by closing the following valves:

*54-24-025, IA Discharge to River/Retention 54-24-030, IA Recirc. and Inlet to 3000-Gal Tank 54-24-013, Ret。Tank 1B Outlet

\footnotetext{
*denotes locked valve
} 
LACBWR Operating Manual

Volume VII, Waste Collection and Treatment
April, 1968

Revised October, 1968

54-24-014, Ret. Tanks Transfer Pump Discharge

*54-24-017, Ret. Tank Discharge to River or Waste Water Storage Tanks

and by opening valve:

54-24-029, IA Recirc. and Inlet to 4500-Gal Tank

Alternate: Close valves:

54-24-173, IB Discharge to River/Retention

54-24-174, IB Recirc. and Inlet to 3000-Gal Tank

54-24-175, IB Recirc. and Inlet to 4500-Gal Tank

\subsubsection{Retention Tank 1B Transfer to Evaporator Feed Tank}

Waste water with a high suspended solids content, or with conductivity greater than $20 \mu \mathrm{mho} / \mathrm{cm}$, and having a radioactivity level too high for discharge to the river, is transferred to the evaporator feed tank where it can be treated prior to concentration in the evaporator.

Prerequisites

1. The reactor building and waste treatment building main floor sections of the Liquid Waste Collection and Treatment Valve Checklist have been completed.

2. Procedure 5.4.3, Retention Tank IB Recirculation, has been completed.

3. The evaporator feed tank is empty.

Procedure

1. Discontinue recirculation of retention tank IB by stopping the retention tanks transfer pump by depressing the STOP button at the local pump control station.

2. Close valve 54-24-143, Ret. Tank IB Recirculation, and open valve 54-24016, Ret. Tanks Pump Discharge to Evap. Feed Tank or Radwaste Ion Exch.

3. Open valve 54-25-006, Liquid Waste Containment Isolation, by depressing the OPEN button at the remote valve control station in the waste treatment building.

4. Start the retention tanks transfer pump by depressing the START button of the remote pump control station in the waste treatment building.

*denotes locked valve 
5. Allow the pump to operate until the evaporator feed tank local level indicator reaches $90 \mathrm{in.;}$ then, stop the pump by depressing the STOP button at the remote pump control station in the waste treatment building.

6. Proceed to the appropriate procedure for evaporation of the water in the evaporator feed tank.

7. When the feed tank is empty, return to steps 4,5 , and 6 above affer each batch until retention tank IB is empty.

8. Return the system to normal by opening valve 54-24-011, Ret. Tank IB Inlet, and closing the following valves:

*54-24-016, Ret. Tanks Pump Discharge to Evap. Feed Tank or Radwaste lon Exchanger

54-25-006, Liquid Waste Containment Isolation

54-24-014, Ret. Tanks Transfer Pump Discharge

54-24-010, Ret. Tank 1A Inlet

54-24-013, Ret. Tank 1B Outlet

\subsubsection{Retention Tank IB Transfer to the Radwaste lon Exchanger}

Waste water with a low suspended solids content and with a conductivity less than 20 $\mu \mathrm{mho} / \mathrm{cm}$ but with a radioactivity level too high for discharge to the river is transferred to the radwaste ion exchanger for cleanup. The water is then collected in the water collection tank, where it is sampled and analyzed for activity, conductivity, $\mathrm{pH}$ and chlorides. If the waste analysis confirms that the quality of the water is satisfactory, it then is discharged to the main condenser hotwell, or it can be discharged to the river via the main condenser circulating water system.

'Prerequisites

1. The reactor building and waste treatment building main floor sections of the Liquid Waste Collection and Treatment Valve Checklist have been completed.

2. The retention tanks transfer pump is ready for operation.

3. Procedure 5.4.3, Retention Tank IB Recirculation, has been completed.

4. The water collection tank is empty.

*denotes locked valve 
LACBWR Operating Manual

Volume VII, Waste Collection and Treatment
April, 1968

Revised October, 1968

Procedure

I. Discontinue recirculation of retention tank IB by stopping the retention tanks transfer pump by depressing the STOP button at the local pump control station.

2. Close 54-24-143, Ret. Tank 1B Recirculation, and open valve 54-24-016, . Ret. Tanks Pump Discharge to Evap. Feed Tank or Radwaste lon Exch.

3. Close valve 54-24-043, Evap. Feed Tank Inlet from Retention and Waste Storage Tanks, and open valve 54-24-088, Radwaste Exch. Water Outlet.

4. Open valve 54-25-006, Liquid Waste Containment Isolation, by depressing the OPEN button at the remote valve control station in the waste treatment building.

5. Start the retention tank transfer pump by depressing the START button at the remote pump control station in the waste treatment building. Immediately establish $20 \mathrm{gpm}$ flow through the ion exchanger by opening valve 54-24-087, Radwaste Exch. Inlet, and observing the flow indicator on the waste treatment building control panel.

6. As the collecting tank is filling, periodically monitor the inlet and outlet conductivity meter on the waste treatment building control panel to determine the quality of the water out of the resin bed.

7. Allow the pump to operate until the level in the water collecting tank reaches $90 \mathrm{in}$. as observed on the local level indicator, and then stop the pump by depressing the STOP button at the remote pump control station in the waste treatment building.

8. Withdraw a sample from the water collecting tank, and analyze it for activity, conductivity, $\mathrm{pH}_{\theta}$ and chlorides to determine the quality of the water. If the water is within the primary water specifications, it can be sent to the main condenser hotwell.

9. After the water collection tank is emptied, repeat steps 5, 6, 7, and 8 ábove until retention tank IB is empty.

10. Return the system to normal by opening valve 54-24-011, Ret. Tánk IB Inlet, 54-24-043, Evap. Feed Tank Inlet from Retention and Waste Storage Tanks, and by closing the following valves:

54-24-010, Ret. 1A Inlet

54-24-013, Ret. IB Outlet

54-24-014, Ret. Tank Transfer Pump Discharge

*54-24-016, Ret. Tanks Pump Discharge to Evap. Feed Tank or Radwaste Ion Exch.

54-25-006, Liquid Waste Containment Isolation

*denotes locked valve 


\subsubsection{Retention Tank IB Discharge to Standpipe}

The liquid waste in retention tank $1 B$ is discharged to the river via the main condenser circulating water system. This is done only after a water analysis of the tank contents confirms that the radioactivity level is such that discharge to the river can take place without further processing.

\section{Prerequisites}

1. The reactor building, tunnel and waste water storage area, and the turbine building sections of the Liquid Waste Collection and Treatment Valve Checklist have been completed.

2. Procedure 5.4.3, Retention Tank IB Recirculation, has been completed.

3. The liquid waste batch form has been prepared, and the water analysis confirms that the radioactivity level of the water is such that it may be discharged to the standpipe.

4. The maximum rate of discharge to the standpipe has been determined, and the required dilution flow rate has been established.

5. The liquid waste and service water and the turbine condenser cooling water radiation monitors are in service.

Procedure

1. Open valves 54-24-017, Ret. Tanks Pump Discharge to River or Waste Storage Tanks, and 54-24-026, Waste System Discharge to River.

2. Open valve 54-25-006, Liquid Waste Containment Isolation, by depressing the OPEN button at the local valve control station.

3. Throttle valve 54-24-143, Ret. Tank 1B Recirculation, to obtain 55 psig at the pump discharge.

4. Ensure that the liquid waste batch form has been properly filled out and that permission has been given by the shift supervisor to discharge the waste water.

5. Commence discharging the water to the standpipe by opening valve 54-23-041, Flow Totalizer Outlet to Radiation Monitor, and observing the radiation monitor flow indicator to obta in the desired flow rate. If the desired discharge rate is greater than 15 $\mathrm{gpm}$, pass additional water to the standpipe by opening valve 54-24-146, Flow Totalizer Outlet to Standpipe. Obtain the flow rate by averaging three 1 -min readings from the flow totalizer. If full flow is desired, close valve 54-24-143, Ret. Tank. IB Recirculation. 
6. Monitor both liquid radiation monitors during the entire discharge of the liquid waste. If either monitor alarms, stop discharging the waste and determine cause of the alarm.

7. The retention tanks transfer pump will stop automatically when the level in the retention tank drops to $6 \mathrm{in}$. When this occurs, complete the liquid waste batch form, and notify the control room. Flush lines and liquid waste radiation monitor in accordance with Sec. 5.4.34.

8. Place retention tank $1 B$ back in service by opening valve 54-24-011, Ret. Tank IB Inlet, and closing valves 54-24-010, Ret. Tank IA Inlet, and 54-24-013, Ret. Tank IB Outlet.

9. Return the system to normal by closing the following valves:

54-24-146, Flow Totalizer Outlet to Standpipe 54-23-041. Flow Totalizer Outlet to Radiation Monitor *54-24-026, Waste System Discharge to River *54-24-017, Ret. Tanks Pump Discharge to River or Waste Storage Tanks 54-24-143, Ret. Tank 1B Recirculation 54-24-014, Ret. Tanks Pump Discharge

10. Close valve 54-25-006, Liquid Waste Containment isolation, by depressing the CLOSE button at the local valve control station. Notify the control room that the system has been returned to normal.

\subsubsection{Retention Tank 1B Recirculation Through Portable Demineralizer}

Retention tank IB cannot be isolated for this operation. Therefore, after completing the operation, immediately proceed to the next desired operation; otherwise, the analysis may be changed by water entering the tark.

\section{Prerequisites}

1. The reactor building section of the Liquid Waste Collection and Treatment Valve Checklist has been completed.

2. The portable demineralizer is ready for operation.

Procedure

1. Connect portable demineralizer inlet to connection at valve 54-24-069, Portable Demineralizer Inlet.

"denotes locked valve 
2. Connect portable demineralizer outlet to connection at valve 54-24-070, Portable Demineralizer Outlet.

3. Open valves 54-24-069, Portable Demineralizer Inlet, 54-24-070, Portable Demineralizer Outlet, and 54-24-013, Ret. Tank Outlet.

4. Start the portable demineralizer pump.

5. After one complete volume change has taken place open valve 54-23-007, Retention Tank IB Sample, and draw a sample for analysis. Analyze the sample to determine radioactivity level, and record data.

6. Continue until water is of the quality required for discharging it to the river, or for the purpose desired.

7. When operation is completed, stop the portable demineralizer pump.

8. Close valves 54-24-070, Portable Demin. Outlet, 54-24-069, Portable Demin. Inlet ${ }_{\text {o }}$ and 54-24-013, Ret. Tank Outlet.

9. Disconnect the portable demineralizer from valves 54-24-069, Portable Demineralizer Inlet, and 54-24-070, Portable Demineralizer Outlet.

10. Proceed to the desired operation to be performed.

\subsubsection{0-Gal Storage Tank Recirculation}

The 3000-gal tank is isolated from the remainder of the system in order to assure that the sample of the contents will be representative and will not be altered by possible addition of liquid waste. The tank contents are recirculated for at least one volume change to obta in a homogeneous mixture. After the sample has been withdrawn, recirculation is continued until permission for disposal has been obtained.

\section{Prerequisites}

1. The turbine building and tunnel and waste water storage area sections of the Liquid Waste Collection and Treatment Valve Checklist have been completed.

2. The storage tanks transfer pump is ready for operation.

3. Procedure 5.4.13, Waste Treatment Building, Gas Storage Vault, and the Turbine Building Sump Pumps Discharge to Retention Tanks, has been completed. 
LACBWR Operating Manual

Volume VII, Waste Collection and Treatment

April, 1968

Revised October, 1968

Procedure

NOTE: The preferred method is to use the IA pump using the normal procedure steps. The alternate procedure steps use IB pump and if it is used, the seal water in-leakage will be adding water to the storage tank; also the possibility exists that the sample from IB discharge may not be truly representative.

1. Determine the number of gallons of water in the tank by observing the local gauge glass and using the tank capacity curve. (Fig , 5.4-4)

2. Divide the number of gallons in the tank by pump capacity to determine the minimum time for recirculation before withdrawing the sample.

3. Open valves 54-24-030, IA Recirc and Inlet to 3000-Gal, and 54-24-032, 3000-Gal Tank Suction to IA.

Alternate: Open valves 54-24-174, 1B Recirc。 and Inlet to 3000-Gal, and 54-24-169, 3000-Gal Tank Suction 1B.

NOTE: Where the alternate path is selected, then all the alternate valves in the entire procedure must be used.

4. Isolate 3000-Gal Waste Water Storage Tank in accordance with steps 1, 2, and 3 of Sec. 5.4.13.

5. Start the storage tanks transfer pump by depressing the START button at the local pump control station (IA for normal procedure; alternate, $1 B$ ). Observe that the pump is operating satisfactorily.

6. Circulate the contents for at least one volume change; then, withdraw a sample at the pump discharge while the system is recirculating.

7. After the sample has been analyzed in the laboratory, proceed to the appropriate procedure for disposal.

\subsubsection{0-Gal Waste Water Storage Tank Transfer to Evaporator Feed Tank}

Waste water with a high suspended-solids content, or with conductivity greater than $20 \mu \mathrm{mho} / \mathrm{cm}$, and with a radioactivity level too high for discharge to the river, is transferred to the evaporator feed tank where it can be treated prior to concentration in the evaporator. 
LACBWR Operating Manual

Volume VII, Waste Collection and Treatment
April, 1968

Revised October, 1968

Prerequisites

1. The tunnel and waste water storage area and the waste treatment building main floor section of the Liquid Waste Collection and Treatment Valve Checklist have been completed.

2. Procedure 5.4.9, 3000-Gal Storage Tank Recirculation, has been completed.

3. The evaporator feed tank is empty.

Procedure

1. Open valve 54-24-024, IA Discharge to Evap. Feed Tank/Radwaste lon Exchanger; alternate, open valve 54-24-172, IB Discharge to Evap. Feed Tank/Radwaste lon Exchanger.

NOTE: When the alternate path is selected, then all the alternate valves in the entire procedure must be used.

2. Close valve 54-24-030, IA Recirc, and Inlet to $3000 \mathrm{Gal}$. Alternate, close valve 54-24-174, IB Recirc, and Inlet to $3000 \mathrm{Gal}$.

3. Allow the pump to operate until the evaporator feed tank local level indicator reaches $90 \mathrm{in}$; ; then, stop the pump by depressing the STOP button at the remote pump control station in the waste treatment building.

4. Proceed to appropriate procedure for treatment of the water in the feed tank prior to evaporation.

5. After the feed tank is empty, return to steps 3 and 4 above until the 3000 -gal storage tank is empty.

6. Return the system to normal by closing the following valves:

*54-24-024, 1A Discharge to Evap. Feed Tank/Radwaste lon Exchanger

Alternate: *54-24-172, 1B Discharge to Evap. Feed Tank/Radwaste lon Exchanger

Alternate: $54-24-169,3000-G$ al Suction to $1 \mathrm{~B}$

54-24-018, Outside Sump Pumps Discharge to Retention Tanks

54-25-006, Liquid Waste Containment Isolation

and opening valve 54-24-153,3000-Gal Tank Inlet from Turbine Bldg. Waste Treatment Bldg. and Gas Vault Sumps.

*denotes locked valve 


\subsubsection{0-Gal Storage Tank Transfer to Radwaste lon Exchanger}

Waste water with a low suspended-solids content and with a conductivity less than 20 $\mu_{m h o} / \mathrm{cm}$ but with a radioactivity level too high for discharge to the river, is transferred to the radwaste ion exchanger for cleanup. The water is then collected in the water collection tank, where it is sampled and analyzed for activity, conductivity, $\mathrm{pH}$, and chlorides. If the waste analysis confirms that the quality of the water is satisfactory, it then is discharged to the main condenser hotwell, or it can be discharged to the river via the main condenser circulating water system.

Prerequisites

1. The tunnel and waste water storage areas and the waste treatment building main floor sections of the Liquid Waste Collection and Treatment Valve Checklist have been completed:

2. Procedure $5.4 .9,3000-$ Gal Storage Tank Recirculation, has been completed.

3. The water collection tank is empty.

Procedure

1. Close valve 54-24-043, Evap. Feed Tank Inlet from Retention and Waste Storage Tanks, and open valve 54-24-088, Radwaste Exch. Water Outlet.

2. Open valve 54-24-024, IA Discharge to Evap. Feed Tank/Radwaste Ion Exchanger.

Alternate: 54-24-172, IB Discharge to Evap. Feed Tank/Radwaste Ion Exchanger.

NOTE: When the alternate path is selected, then all the alternate valves in the entire procedure must be used.

3. Throttle valve 54-24-030 to obtain 50 psig at the lA pump discharge .

Alternate: throttle valve 54-24-174, .1B Recirc. Inlet to 3000 . Gal to obtain 50 psig at the IB pump discharge.

4. Open valve 54-24-087, Radwaste Exch. Inlet, as required to obtain a flow rate of $20 \mathrm{gpm}$ as indicated on the flow meter on the waste treatment building control panel. 
5. As the water collecting tank is filling, periodically monitor the inlet and outlet conductivity meter on the waste treatment building control panel to determine the quality of the water out of the resin bed.

6. Allow the flow to continue until the water collecting tank reaches $90 \mathrm{in.;}$ then, close valve 54-24-087, Radwaste Exch. Inlet.

7. Withdraw a sample from the water collecting tank, and analyze it for activity, conductivity, $\mathrm{pH}$, and chlorides to determine the quality of the water. If the water is within the primary water specifications, it can be sent to the main condenser hotwell.

8. After the water collection tank is emptied, repeat steps 4, 5, 6, and 7 until the 3000 -gal tank is empty.

9. Return the system to normal by opening valve 54-24-043, Evap. Feed Tank Inlet from Retention and Waste Storage Tanks, and closing the following valves:

54-24-032, 3000-Gal Suction to IA

Alternate: $54-24-169,3000-$ Gal Suction to 1B

54-24-030, IA Recirc, and Inlet to $3000 \mathrm{Gal}$

Alternate: $54-24-174,1 \mathrm{~B}$ Recirc, and Inlet to $3000 \mathrm{Gal}$

*54-24-024, IA Discharge to Evap. Feed Tank/Radwaste lon Exchanger Alternate: *54-24-172, IB Discharge to Evap. Feed Tank/Radwaste lon Exchanger

54-24-087, Radwaste Exch. Inlet

54-24-088, Radwaste Exch. Water Outlet

*54-24-018, Outside Sump Pumps Discharge to Retention Tank

54-25-006, Liquid Waste Containment Isolation

\subsubsection{0-Gal Storage Tank Discharge to Standpipe}

The liquid waste in the 3000 -gal storage tank is discharged to the river via the ma in condenser circulating water system. This is done only after a water analysis of the tank contents confirms that the radioactivity level is such that discharge to the river can take place without further processing.

\section{Prerequisites}

1. The turbine building and the tunnel and waste water storage area sections of the Liquid Waste Collection and Treatment Valve Checklist have been completed.

\footnotetext{
*denotes locked valve
} 
2. Procedure 5.4.9, 3000-Gal Waste Water Storage Tank Recirculation, has been completed.

3. The liquid waste batch form has been prepared, and the water analysis confirms that the radioactivity level of the water is such that it may be discharged to the standpipe.

4. The maximum rate of discharge to the standpipe has been determined, and the required dilution flow. rate has been established.

5. The liquid waste and service water and the turbine condenser cooling water radiation monitors are in service.

Procedure

1. Open valves 54-24-025, IA Discharge to River/Retention, and 54-24-026, Waste System Discharge to River.

Alternate: 54-24-173, 1B Discharge to River/Retention, and 54-24-026, Waste System Discharge to River.

NOTE: Where the alternate path is selected, then all the alternate valves in the entire procedure must be used.

2. Throttle valve 54-24-030, 3000-Gal Storage Tank Inlet from Retention Tank, to obtain 50 psig at the pump discharge.

3. Ensure that the liquid waste batch form has been properly filled out and that permission has been given by the shift supervisor to discharge the waste water.

4. Commence discharging the water to the standpipe by opening valve 54-23-04 I, Flow Totalizer Outlet to Radiation Monitor, and observing the radiation monitor flow indicator to obtain the desired flow rate. If the desired discharge rate is greater than 15 $\mathrm{gpm}$, pass the additional water to. the standpipe by opening valve 54-24-146, Flow Totalizer Outlet to Standpipe.

5. Obtain the flow rate by averaging three $1-\mathrm{m}$ in readings from the flow totalizer. If full flow is desired, close valve 54-24-030, 1A Recirc. and Inlet to $3000 \mathrm{Gal}$.

Alternate: Close 54-24-174, 1B Recirc, and Inlet to $3000 \mathrm{Gal}$.

6. Monitor both liquid radiation monitors during the entire discharge of the liquid waste. If either monitor alarms, stop discharging waste and determine cause of the alarm. 
7. The storage tank transfer pump will stop automatically when the level in the tank drops to 6 in. When this occurs, complete the liquid waste batch form, and notify. the control room. Flush lines and liquid waste radiation monitor in accordance with Procedure 5.4.34.

8. Place the 3000-gal storage tank back in service by opening valve $54-24-153$, 3000-Gal Tank. Inlet from Turbine Bldg., Waste Treatment Bldg., and Gas Vault.

9. Return the system to normal by closing the following valves:

$54-24-032,3000$ Suction to $1 \mathrm{~A}$

Alternate: $54-24-169,3000$ Suction to 1B.

54-24-030, 1A Recirc. and Inlet to $3000 \mathrm{Gal}$

Alternate: $54-24-174$, IB Recirc, and Inlet to 3000 Gal.

*54-24-025, IA Discharge to River/Retention Alternate: *54-24-173, 1B Discharge to River/Retention

*54-24-026, Waste System Discharge to River 54-23-041, Flow Totalizer Outlet to Radiation Monitor 54-24-146, Flow Totalizer Outlet to Standpipe *54-24-018, Outside Sump Pump Discharge to Retention Tank

10. Close valves 54-25-006, Liquid Waste Containment Isolation, by depressing the CLOSE button at the local valve control station. Notify the control room that the system has been returned to normal.

5.4.13 Waste Treatment Building, Gas Storage Vault, and the Turbine Building Sump Pumps Discharge to Retention Tanks

Whenever the 3000 -gal waste water storage tank is isolated, the sump pumps must be routed to the retention tank in service.

\section{Prerequisite}

1. The reactor building and tunnel and waste water storage area section of the Liquid Waste Collection and Treatment Valve Checklist has been completed.

\section{Procedure}

1. Open valve 54-24-018, Outside Sump Pumps Discharge to Retention Tanks.

\footnotetext{
*denotes locked valve
} 
2. Open valve 54-25-006, Liquid Waste Containment Isolation, by depressing the OPEN button at the local valve control station.

3. Close valve 54-24-153, 3000-Gal Tank Inlet from Turbine Bldg., Waste Treatment Bldg., and Gas Vault Sumps. Sumps are now lined up to retention tank in service.

4. When the 3000-gal storage tank is placed back in service, return the system to normal by reversing the position of the valves listed in steps 1,2, and 3 above. System is now back to normal.

\subsubsection{0-Gal Storage Tank Recirculation}

The 4500-gal tank is isolated from the remainder of the system in order to assure that the sample of the contents will be representative and will not be altered by the possible addition of liquid waste. The tank contents are recirculated for at least one volume change to obtain a homogeneous mixture. After the sample has been withdrawn, recirculation is continued until permission for disposal has been obtained.

Prerequisites

1. The tunnel and waste water storage area section of the Liquid Waste Collection and Valve Checklist has been completed.

2. The storage tank transfer pump is ready for operation.

3. The condensate demineralizer regeneration operations must not be in progress.

Procedure

NOTE: The preferred method is to use the IA pump using the normal procedure steps. The alternate procedure steps use IB pump and if it is used, the seal water in-leakage will be adding water to the storage tank, also the possibility exists that the sample from the IB discharge may not be truly representative.

1. Isolate the tank by opening valve 54-24-036, 3000-Gal Storage Tank 6-In. Inlet, and closing valves 54-24-035, 4500-Gal Storage 6-In. Inlet, and 54-24-037, 4500-Gal Storage Tank 4-In. Inlet.

2. Line up the low level pump cutoff switches to the 4500 -gal storage tank by closing valve 54-28-014, Low Level Pump Cut-Off Switches Isolation from 3000-Gal Tank, and by opening valve 54-28-045, Low Level Pump Cut-Off Switches Isolation from 4500-Gal Tank. 
3. Determine the number of gallons of water in the tank by observing the local gauge glass and using the tank capacity curve. (Fig, 5.04-3)

4. Divide the number of gallons in tank by the pump capacity to determine the minimum time for recirculation.

5. Open valves 54-24-031, 4500-Gal Suction to $1 \mathrm{~A}$, and 54-24-029, IA Recirc. and Inlet to $4500 \mathrm{Gal}$.

Alternate: Open valves 54-24-170, 4500-Gal Suction to $1 \mathrm{~A}$, and 54-24175, IB Recirc. and Inlet to $4500 \mathrm{Gal}$.

NOTE: When the alternate path is selected, then all the alternate valves in the entire procedure must be used.

6. Start the storage tanks transfer pump by depressing the START button at the local pump control station. Observe that the pump is operating satisfactorily. IA for normal procedure; alternate, IB.

7. Circulate the contents for at least one volume change; then, withdraw a sample at the pump discharge while the system is recirculating.

8. After the sample has been analyzed in the laboratory, proceed to the appropriate procedure for disposal.

\subsubsection{0-Gal Storage Tank Transfer to Evaporator Feed Tank}

Waste water with a high suspended-solids content or with conductivity greater than 20 $\mu \mathrm{mho} / \mathrm{cm}$ and a radioactivity level too high for discharge to the river, is transferred to the evaporator feed tank where it can be treated prior to concentration in the evaporator.

\section{Prerequisites}

1. The tunnel and waste water storage area and the waste treatment building main floor sections of the Liquid Waste Collection and Treatment Valve Checklist have been completed.

2. Procedure 5.4.14,4500-Gal Storage Tank Recirculation, has been completed.

3. The evaporator feed tank is empty. 
LACBWR Operating Manual

Volume VII, Waste Collection and Treatment
April, 1968

Revised October, 1968

Procedure

1. Open valve 54-24-024, IA Disch. to Evap. Feed Tank/Radwaste lon Exchanger.

Alternate: Open valve 54-24-172, 1B Discharge to Evap. Feed Tank/Radwaste Ion Exchanger.

NOTE: When the alternate path is selected, then all the alternate valves in the entire procedure must be used.

2. Close valve 54-24-029, IA Recirc, and Inlet to $4500 \mathrm{Gal}$.

Alternate: Close valve 54-24-175, 1B Recirc。 and Inlet to $4500 \mathrm{Gal}$.

3. Allow the pump to operate until the evaporator feed tank local level indicator reaches $90 \mathrm{in}$.; then, stop pump by depressing the STOP button at the remote pump control station in the waste treatment building. tion.

4. Proceed to appropriate procedure for treatment of feedwater prior to evapora-

5. After the feed tank is empty, repeat steps 3 and 4 above until the 4500 -gal tank is empty.

6. Return the system to normal by closing the following valves:

54-24-029, 1A Recirc and Inlet to $4500 \mathrm{Gal}$

Alternate: $54-24-175, .1 \mathrm{~B} \mathrm{Recirc}$ and Inlet to $4500 \mathrm{Gal}$

54-28-045, Low Level Pump Cut-Off Switch Isolation from 4500-Gal Tank

54-24-031, 4500-Gal Tank Suction to IA

$54 \div 24=036,: 3000-$ Gal Storage Tank 6-In。 Inlet

and opening the following valves:

54-24-035, 4500-Gal Storage Tank 6-In. Inlet 54-24-037, 4500-Gal Storage Tank 4-In. Inlet

54-28-01A, Low Level Pump Cut-Off Switch Isolation from 3000-Gal Tank

\subsubsection{0-Gal Storage Tank Transfer to Radwaste lon Exchanger}

Waste water with a low suspended-solids content and with a conductivity less than 20 $\mu \mathrm{mho} / \mathrm{cm}$ but with a radioactivity level too high for discharge to the river is transferred to the radwaste ion exchanger for cleanup. The water is then collected in the water 
collection tank, where it is sampled and analyzed for activity, conductivity, $\mathrm{pH}$, and chlorides. If the waste analysis confirms that the quality of the water is satisfactory, it is then discharged to the main condenser hotwell, or it can be discharged to the river via the main condenser circulating water system.

Prerequisites

1. The tunnel and waste water storage areas and the waste treatment building main floor sections of the Liquid Waste Collection and Treatment Valve Checklist-have been completed.

2. Procedure 5.4.14,4500-Gal Storage Tank Recirculation, has been completed.

3. The water collection tank is empty.

Procedure

1. Close valve 54-24-043, Evap. Feed Tank Inlet from Retention and Waste Storage Tanks, and open valve 54-24-088, Radwaste Exch. Water Outlet.

2. Open valve 54-24-024, IA D ischarge to Evap. Feed Tank/Radwaste Ion Exch.

Alternate: Open valve 54-24-172, IB Disch. to Evap. Feed Tank/Radwaste Ion Exch.

NOTE: Where the alternate path is selected, then all the alternate valves in the entire procedure must be used.

3. Throttle valve 54-24-029, IA Recirc and Inlet to $4500 \mathrm{Gal}$, to obtain 50 psig at the pump discharge.

Alternate: Throttle valve 54-24-175, 1B Recirc. and Inlet to $4500 \mathrm{Gal}$ to obtain 50 psig at $1 B$ pump discharge.

4. Open valve 54-24-087, Radwaste Exch. Inlet, as required to obtain a flow rate of $20 \mathrm{gpm}$ as indicated on the flowmeter on the waste treatment building control panel.

5. As the water collecting tank is filling, periodically monitor the inlet and outlet conductivity meter on the waste treatment building control panel to determine the quality of the water out of the resin bed. 
6. Allow the flow to continue until the water collecting tank reaches 9,0 in.; then, close valve 54-24-087, Radwaste Exch. Inlet.

7. Withdraw a sample from the water collecting tank, and analyze it for activity, conductivity, $\mathrm{pH}$, and chlorides to determine quality of water. If the water is within the primary water specifications, it can be sent to the main condenser hotwell.

8. After the water collection tank is emptied, repeat steps 4, 5, 6, and 7 until the 4500-gal tank is empty.

9. Place the 4500-gal storage tank back in service by opening valves 54-24-037, 4500-Gal. Storage Tank 4-In. Inlet, 54-24-035, 4500-Gal Storage Tank 6-In. Inlet, and closing valve 54-24-036, 3000-Gal Storage Tank 6-In. Inlet.

10. Return the system to normal by closing the following valves:

54-24-087, Radwaste Exch. Inlet

54-24-088, Radwaste Exch. Outlet

*54-24-024, IA Disch. to Evap. Feed Tank/Radwaste lon Exch.

Alternate: 54-24-172, IB Disch. to Evap. Feed Tank/Radwaste lon Exch.

54-24-045, Low Level Pump Cut-Off Switch Isolation from 4500-Gal Tank

54-24-031, 4500-Gal Suction to IA

Alternate: $54-24-170,4500-G$ al Suction to IB

54-24-029, IA Recirc and Inlet to $4500 \mathrm{Gal}$

Alternate: $54-24-175,1 B$ Recirc and Inlet to $4500 \mathrm{Gal}$

and opening valves:

54-28-014, Low Level Pump Cut-Off Switch Isolation from 3000-Gal Tank 54-24-043, Evap. Feed Tank Inlet from Retention and Waste Storage Tanks

\subsubsection{0-Gal Storage Tank Discharge to Standpipe}

The liquid waste in the 4500-gal storage tank is discharged to the river via the main condenser circulating water system. This is done only after a water analysis of the tank contents confirms that the radioactivity level is such that discharge to the river can take place without further processing.

\section{Prerequisites}

1. The turbine building and the tunnel and waste water storage area sections of the Liquid Waste Collection and Treatment Valve Checklist have been completed.

*denotes locked valve 
LACBWR Operating Manual

Volume VII, Waste Collection and Treatment
April, 1968

Revised October, 1968

2. Procedure 5.4.14, 4500-Gal Waste Water Storage Tank Recirculation, has been completed.

3. The liquid waste batch form has been prepared, and the water analysis confirms that the radioactivity level of the water is such that it may be discharged to the standpipe.

4. The maximum rate of discharge to the standpipe has been determined, and the required dilution flow rate has been established.

5. The liquid waste and service water and the turbine condenser cooling water radiation monitors are in service.

Procedure

1. Open valves 54-24-025, 1A Disch. to River/Retention.

Alternate: $54-24-173$, IB Disch. to River/Retention; and 54-24-026, Waste System Discharge to River.

NOTE: When the alternate path is selected, then all the altemate valves in the entire procedure must be used.

2. Throttle valve 54-24-029, IA Recirc and Inlet to $4500 \mathrm{Gal}$ to obtain 50 psig at 1 A pump discharge.

Alternate: Throttle valve 54-24-175, IB Recirc, and Inlet to $4500 \mathrm{Gal}$ to obtain 50 psig at 1 B pump discharge.

3. Ensure that the liquid waste batch form has been properly filled out, and that permission has been given by the shift supervisor to discharge the waste water.

4. Commence discharging the water to the standpipe by opening valve 54-23-041, Flow Totalizer Outlet to Radiation Monitor, and observing the radiation monitor flow indicator to obtain the desired flow rate. If the desired discharge rate is greater than 15 $\mathrm{gpm}$, pass the additional water to the standpipe by opening valve $54-24-146$, Flow Totalizer Outlet to Standpipe.

5. Obtain the flow rate by averaging three 1 -min readings from the flow totalizer. If full flow is desired, close valve 54-24-029, IA Recirc. and Inlet to $4500 \mathrm{Gal}$.

Altemate: If full flow is desired, close valve 54-24-175, 1B Recirc. and Inlet to $4500 \mathrm{Gal}$. 
6. Monitor both liquid radiation monitors during the entire discharge of the liquid waste. If either monitor alarms, stop discharging waste, and determine cause of the alarm.

7. The storage tank transfer pump will stop automatically when the level in the tank drops to $6 \mathrm{in}$. When this occurs, complete the liquid waste batch form and notify the control room. Flush lines and liquid waste radiation monitor in accordance with Sec. 5.4.3.4.

8. Place the 4500-gal.storage tank back in service by opening valves 54-24-037, 4500-Gal Storage Tank 4-In. Inlet, 54-24-035, 4500-Gal Storage Tank 6-In. Inlet, and by closing valve $54-24-036,3000-G$ al Storage Tank 6-In. Inlet.

9. Return the system to normal by closing the following valves:

54-24-031,4500-Gal Tank Suction to IA

Alternate: $54-24-170,4500-\mathrm{Gal}$ Suction to IB

*54-24-025, Storage Tanks Discharge to River/Retention

*54-24-026, Waste System Discharge to River

54-23-04 I, Flow Totalizer Outlet to Radiation Monitor

$54-24-146$, Flow Totalizer Outlet to Standpipe

and opening valve 54-28-014, Low Level Pump Cut-Off Switch Isolation from 3000-Gal Tank.

\subsubsection{Change Room Drain Tank Recirculation}

The water from the sinks, showers, and washers in the waste treatment building and turbine building change room and grade floor are collected in the drain tank. The water will normally be low in radioactivity content but will be laden with various soaps and detergents. Contents of this tank are normally to be drained to the waste water tanks. If conditions, such as (1) full waste tanks, (2) probable disposition of the water in waste tanks to the evaporator or radwaste ion exchanger, etc, do not perm it disposal in the normal manner, the tank can be recirculated, sampled, and disposed of by discharging to the standpipe. Since the dra in tank cannot be isolated from its sources, signs must be displayed at these sources to alert individuals not to use except in emergencies.

\section{Prerequisites}

1. The turbine building sections of the Liquid Waste Collection and Treatment Valve Checklist have been completed.

*denotes locked valve 
2. The change room drain tank transfer pump is ready for operation.

Procedure

1. Display signs labeled DO NOT USE EXCEPT IN EMERGENCY at each of the sources listed below:

(a) Waste Treatment Building Shower

(b) Waste Treatment Building Sink

(c) Change Room Showers (two)

(d) Change Room Deepsink

(e) Change Room Washer

(f) Grade Level Washer

2. Determine the minimum recirculation time by observing the local level. indicator at the drain tank and dividing the number of gallons of water in the tank by the pump capacity $(10 \mathrm{gpm})$.

3. Open valve 54-23-164, Change Room Drain Tank Recirculation.

4. Start the change room drain tank transfer pump by placing the local pump control switch to $O N$. Confirm by observation that the pump is operating satisfactorily.

5. After the tank contents have recirculated for at least one volume change, withdraw sample.

6. Proceed to appropriate procedure for disposal.

\subsubsection{Change Room Drain Tank Discharge to Standpipe}

The dra in tank is discharged to the standpipe after a sample of the tank contents confirms that the radioactivity level is such that discharge can take place.

\section{Prerequisites}

1. The turbine building and tunnel and waste water storage area sections of the Liquid Waste Collection and Treatment Valve Checklist have been completed.

2. Procedure 5.4.18, Change Room Drain Tank Recirculation, has been completed.

3. The liquid waste batch form has been prepared, and the water analysis confirms that the radioactivity level is such that it may be discharged to the standpipe. 
LACBWR Operating Manual

Volume VII, Waste Collection and Treatment
April, 1968

Revised October, 1968

4. The maximum rate of discharge to the standpipe has been determined, and the required dilution flow rate has been established.

5. The liquid waste and service water and the turbine condenser cooling water radiation monitors are in service.

Procedures

1. Open valves 54-24-165, Change Room Drain Tank Pump Disch., and 54-24026, Waste System Discharge to River.

2. Ensure that the liquid waste batch form has been properly filled out, and that the water level in the drain tank is at the same level.

3. Ensure that the liquid waste batch form has been properly filled out; and that the drain tank level is the same as it was at the time of sampling. pipe.

4. Obtain permission from the shift supervisor to discharge water to the stand-

5. Commence discharging water by closing valve 54-24-164, Change Room Drain Tank Recirculation, and opening valve 54-23-041, Flow Totalizer Outlet to Radiation Monitor, as required to obtain the desired discharge rate at the flow indicator on the radiation monitor.

NOTE: The pump has no automatic cutoff features; therefore, it must be observed closely during the discharge of water to prevent damage to the pump that would occur if the tank becomes empty.

6. Monitor both liquid radiation monitors during the entire discharge of liquid. waste. If either monitor alarms, stop discharging and determine the cause of the alarm.

7. After completion of waste discharge, stop change room drain tank pump and complete the liquid waste batch form and notify control room. Flush lines and liquid waste radiation monitor in accordance with Sec 5.4.34.

8. Remove the signs that were placed at the various locations in step 1 of Procedure 5.4 .18 .

9. Close valves, 54-23-041, Flow Totalizer Outlet to Radiation Monitor, 54-24026. Waste System Discharge to River, 54-24-165, Change Room Drain Tank Pump Discharge.

10. System is now returned to normal. Notify control room. 
LACBWR Operating Manual

Volume VII, Waste Collection and Treatment

\subsection{Change Room Drain Tank Transfer to Storage Tanks}

Under normal conditions the drain tank is drained to the waste water storage tanks. The storage tank which is lined up to the 6-in. floor drain header will receive the waste water.

Prerequisites

None.

Procedure

1. Line up the 6-in. floor drain system to the waste water storage tank that has been selected to receive the waste water.

2. Open valve 54-23-065, Change Room Drain Tank Drain.

3. After the drain tank is empty, close valve 54-23-065, Change Room Drain Tank Drain, and return the 6-in. floor drain header to the tank in service prior to draining.

4. Notify control room that drain tank is empty.

\subsubsection{Evaporator Feed Tank Recirculation Through Eductor for Chemical Addition}

Chemical additions may be required for the following reasons:

(a) Adjusting $\mathrm{pH}$ of feedwater to $7 \pm \mathrm{I}$.

(b) Adding anti-foaming compounds to reduce foaming from soaps or cleaning agents in the feedwater.

(c) Chemical cleaning of the evaporator bottoms section.

Prerequisites

1. The waste treatment building sections of the Liquid Waste Collection and Treatment Valve Checklist have been completed.

2. The liquid waste demineralizer pump is ready for operation.

3. The evaporator feed tank is filled with the water to be processed, and the chemical mix tank contains the required amount of chemicals to be added to the feedwater. 
LACBWR Operating Manual

Volume VII, Waste Collection and Treatment
April, 1968

Revised October, 1968

Procedure

1. Open valve 52-24-052, Neutralizer Eductor Water Supply.

2. Start the Liquid Waste Demineralizer Pump by depressing the START button at the pump starter on the Waste Treatment Building MCC. Observe that the pump is operating satisfactorily.

3. Slowly open valve 54-24-053, Chemical Mix Tank Outlet to Neutralizer Eductor, and observe the chemical mix tank gauge glass to determine that its level is decreasing.

4. After completion of chemical addition, close valve 54-24-053, Chemical Mix Tank Outlet to Neutralizer Eductor, and continue recirculation.

5. After contents have recirculated $30 \mathrm{~min}$, withdraw sample to determine if chemical addition was satisfactory.

6. If the analysis shows that more chemicals must be added, repeat steps 3,4 , and 5 ; if analysis is then satisfactory, continue to step 7.

7. Stop the liquid waste demineralizer pump by pressing the STOP button at the control station located at the Waste Treatment Building MCC.

8. Close valve 54-24-052, Neutralizer Eductor Water Supply.

9. Open valve 54-23-001, Chem. Mix Tank Outlet to Waste Disposal Bldg. Sump.

10. Open valve 54-24-075, Chem. Mix Tank Demin. Water Supply to rinse chemical mix tank; then, close valve 54-24-075.

1.1. Let tank drain; then close valve 54-23-001, Chem. Mix Tank Outlet to Waste Disposal Bldg. Sump.

12. System is now back in normal operating configuration.

5.4.22 Evaporator Feed Tank Discharge to the Evaporator

Prerequisites

1. The waste treatment building sections of the Liquid Waste Collection and Treatment Valve Checklist have been completed. 
2. The evaporator feed tank is filled with radioactive water having a conductivity greater than $20 \mu \mathrm{mhos} / \mathrm{cm}$ with the proper $\mathrm{pH}$ and to which anti-foaming compounds have been added if required.

3. The heating steam boiler is in operation, and heating steam is available for operating the evaporator.

4. The L.P. service water system is in operation, and it is available for operation of the evaporator condenser.

Procedure

1. Open control valve 54-24-005, Evaporator Inlet Flow Control, by pressing its OPEN pushbutton located on the waste disposal building control panel. (The switch is a maintained-position control switch.)

2. Open valve 54-24-051, Evap。Feed Pump and Liquịd Demin. Pump Discharge to Evaporator.

3. Start the liquid waste demineralizer pump by pressing the START button on the pump START-STOP control switch located on the Waste Treatment Building MCC.

4. When the EVAP LEVEL LO a larm clears, open valve 54-24-085, Evap. Condenser Cooling Water Inlet.

5. Adjust valve 54-24-086, Evap. Condenser Cooling Water Outlet, for a flow of approximately $65 \mathrm{gpm}$ as read on the inlet flow indicator.

6. Open valve 54-25-018, Evaporator Heating Steam Supply, by pressing its OPEN pushbutton located at the waste disposal building control panel. (The switch is a mainta ined-position switch.)

7. Monitor the evaporator temperature and pressure indicators and the level alarms.

8. Once boiling starts, adjust valve 54-24-086, Evap. Condenser Cooling Water Outlet, as required to maintain the condenser cooling water outlet temperature at approximately. $100 \mathrm{~F}$ with the condensate outlet temperature below $120 \mathrm{~F}$.

9. Check the evaporator feed pump to ensure that it is operating. The pump will trip if valve 54-25-005, Evaporator Inlet Flow Control, is fully closed.

10. If the evaporator feed pump has tripped, wait until valve 54-25-005, Evaporator Inlet Flow Control, leaves its full closed position before restarting the pump. 
1.1. Monitor the evaporator during the evaporation process; record data on Data Sheet $5.4,29$.

12. When the EVAP FEED TANK LEVEL HI or LO alarm is actuated on the waste treatment building control panel, check that the evaporator feed pump is stopped. If not, then stop the evaporator feed pump by pressing the STOP button on START-STOP control station located on the Waste Disposal Building MCC.

13. Close valve 54-25-018, Evaporator Heating Steam Supply, by pressing CLOSE pushbutton on its control station located on the waste treatment building control panel.

14. Check the water level in the water collection tank. If sufficient capacity remains, another evaporator feed tank full of waste may be processed, or the water collection tank contents may be transferred to the main condenser hotwell in accordance with Procedure 5.4.24, Waste Collection Tank Discharge to Ma in Condenser Hotwell, or Procedure 5.4.25, Water Collection Tank Discharge to River.

15. Fill Evaporator Feed Tank in accordance with Procedure 5.4.5, 5.4.10, or 5.4 .15

16. Add chemicals as required, utilizing Procedure 5.4.27, and continue evaporation process as follows:

(a) Open valve 54-25-018, Evaporator Heating Steam Supply, by pressing its OPEN pushbutton located on the waste disposal building control panel.

(b) Open valves 54-24-068, Conc. Waste Transfer Pump Suction from LP Service Water Line, 54-24-067, Conc. Waste Transfer Pump Suction Inlet from Liquid Waste Demin. Pump, 54-24-144, Demister Flushing Line, and 54-24-121, Evap. and Evap. Demister Flushing Water Inlet, until a flow of $5 \mathrm{gpm}$ is read on the flushing line flow indicator.

(c) After $2 \mathrm{~min}$, close valves 54-24-121 and 54-24-144.

(d) Repeat steps 6 through 12 .

After the required evaporation operations have been performed, the evaporator is drained, descaled, flushed and then secured.

17. Close control valve 54-25-005, Evaporator Inlet Flow Control, by pressing CLOSE pushbutton on the OPEN-CLOSE control station located on the waste disposal building control panel. 
LACBWR Operating Manual

Volume VII, Waste Collection and Treatment
April, 1968

Revised October, 1968

18. Check concentrated waste tank level to ensure that it can receive the evaporator bottoms.

19. Open valve 54-24-101, Evap. Bottoms Outlet.

20. Open valve 54-24-145, Evap. Flushing Line, and adjust valve 54-24-121, Evap. and Evap. Demister Flushing Water Inlet until a flow of $20 \mathrm{gpm}$ is read on the flushing line flow indicator:

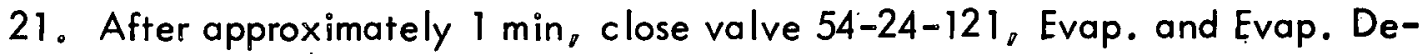
mister Flushing Water Inlet. Wait $5 \mathrm{~min}$, and repeat flushing operation.

22. Close valve 54-24-145, Evap. Flushing Line.

23. Open valve 54-24-144, Demister Flushing Line, and adjust valve 54-24-121, Evap. and Evap. Demister Flushing Water Inlet, until a flow of $5 \mathrm{gpm}$ is obtained.

24. After approximately $2 \mathrm{~min}$, close valves 54-24-121, Evap. and Evap. Demister Flushing Water Inlet, 54-24-144, Demister Flushing Line, 54-24-067, Conc. Waste Transfer Pump Suction Inlet from Liquid Waste Demin. Pump, and 54-24-068, Conc. Waste Transfer Pump Suction from LP Service Water Line.

25. Close valve 54-25-018, Evaporator Heating Steam Supply, by pressing CLOSE pushbutton on its control station located on the waste disposal building control panel.

26. Close valves 54-24-101, Evap. Bottoms Outlet, 54-24-086, Evap. Condenser Cooling Water Outlet, 54-24-085, Evap. Condenser Cooling Water Inlet, and 54-24-051, Evap. Feed Pump and Liquid Demin. Pump Discharge to Evaporator.

27. The system is now back in normal standby configuration. 
LACBWR Operating Manual

Volume VII, Waste Collection and Treatment
April, 1968

Revised October, 1968

DATA SHEET 5-4-22

LIQUUID WASTE EVAPORATION

Date

Time operations inịtiated

Evap. Feed Tank level

Evap. Feed Tank conductivity

Evap. Feed Tank pH

Chemicals added to Evap. Feed Tank to adjust pH and prevent foaming (amts.)

Final Evap. Feed Tank pH

Initial Collection Tank level

Final Collection Tank level

Concentrated Waste Tank level before transfer

After transfer

Operations completed 
LACBWR Operating Manual

Volume V.II, Waste Collection and Treatment
April, 1968

Revised October, 1968

\begin{tabular}{|c|c|c|c|c|c|c|c|c|}
\hline \multirow[b]{2}{*}{ Time } & \multirow{2}{*}{$\begin{array}{l}\text { Evap. } \\
\text { Temp. }\end{array}$} & \multirow{2}{*}{$\begin{array}{l}\text { Evap. } \\
\text { Press. }\end{array}$} & \multirow{2}{*}{$\begin{array}{c}\text { Heating } \\
\text { Steam Press. }\end{array}$} & \multirow[b]{2}{*}{ Cond. Temp. } & \multicolumn{2}{|c|}{ Cond. Service Water } & \multirow{2}{*}{$\begin{array}{l}\text { Evap. } \\
\text { Fd.Tk. } \\
\text { Level }\end{array}$} & \multirow{2}{*}{$\begin{array}{l}\text { Coll. } \\
\text { Tk. } \\
\text { Level }\end{array}$} \\
\hline & & & & & Temp. & Flow & & \\
\hline & & & & & & & & \\
\hline & & & & & & & & \\
\hline & & & & & & & & \\
\hline & & & & & & & & \\
\hline & & & & & & & & \\
\hline & & & & & & & & \\
\hline & & & & & & & & \\
\hline & & & & & & & & \\
\hline & & & & & & & & \\
\hline & & & & & & & & \\
\hline & & & & & & & & \\
\hline
\end{tabular}

Operator

Supervisor 
LACBWR Operating Manual

Volume VII, Waste Collection and Treatment
April, 1968

Revised October, 1968

\subsubsection{Water Collection Tank Recirculation Through Radwaste lon Exchanger}

Water collected in the water collection tank which does not meet the primary water specification can be circulated through the radwaste ion exchanger for additional cleanup.

Prerequisites

1. The waste treatment building sections of the Liquid Waste Collection and Treatment Valve Checklist have been completed.

2. The liquid waste demineralizer pump has been flushed and is ready for operation.

3. The water in the water collection tank is less than $20 \mu \mathrm{mho} / \mathrm{cm}$ and is low in solid content.

Procedure

1. Close valves, 54-24-043, Evap. Feed Tank Inlet from Retention and Waste Storage Tanks, and 54-24-105, Evap. Feed Tank Outlet.

2. Open valves 54-24-062, Water Collection Tank Outlet to Liquid Waste Demin. Pump, 54-24-050, Evap. Feed Pump and Liquid Demin. Pump Discharge to Radwaste Ion Exch., and 54-24-088, Radwaste Exch. Water Outlet.

3. Start liquid waste demineralizer pump by pressing START button on liquid waste demineralizer pump START-STOP control station at the Waste Disposal Building MCC, and immediately open valve 54-24-087, Radwaste lon Exch. Inlet as required to obta in a flow rate of $20 \mathrm{gpm}$ through the exchanger as indicated on the flow indicator on the waste treatment building control panel.

4. Monitor the radwaste ion exchanger outlet on the conductivity indicator located on the waste disposal building control panel. Record flow rate and conductivity every $30 \mathrm{~min}$.

5. Monitor the inlet water conductivity by rotating the conductivity monitor selector switch to INLET and holding switch in this position while reading the conductivity monitor. Record flow rate and conductivity every $30 \mathrm{~min}$.

6. After the desired results have been obtained, stop the liquid waste demineralizer pump by pressing STOP button on the Waste Disposal Building MCC.

7. Open valves 54-24-105, Evap. Feed Tank Outlet, and 54-24-043, Evap. Feed Tank Inlet from Retention and Waste Storage Tanks. 
8. Close valves 54-24-087, Radwaste Ion Exch. Inlet, 54-24-050, Evap. Feed Pump and Liquid Waste Demin. Pump Discharge to Radwaste lon Exch., 54-24-062, Water Collection Tank Outlet to Liquid Waste Demin. Pump, and 54-24-088, Radwaste Exch. Water Outlet. The system is now back on normal operating configuration.

\subsubsection{Water Collection Tank Discharge to Main Condenser Hotwell}

The water in the collecting tank is analyzed; and if the water meets the primary: specifications and is desired for reuse, it is then transferred to the hotwell.

\section{Prerequisites}

1. The waste treatment building main floor section of the Liquid Waste Collection and Treatment Valve Checklist has been completed.

2. The process water transfer pump is ready for operation.

3. The water in the water collection tank has been analyzed and is satisfactory for reuse.

Procedure

1. Check the level of water in the water collection tank, and determine the amount to be transferred using Fig. 5.4-5. Notify the control room that the tranisfer is about to take place.

2. Open valve 54-24-061, Water Collection Tank Outlet to Process Water Transfer Pump.

3. Unlock and open valves 54-24-109, Process Water Discharge to Main Condenser Hotwell, and 54-24-110, Process Water Discharge to Main Condenser Hotwell Shutoff.

4. Start the process water transfer pump by pressing the START button on the process water transfer pump START-STOP control station located on the Waste Disposal Building MCC.

5. Let the pump operate until it is automatically tripped by the lo-level pump cutoff switch or until the desired amount of water has been transferred, at which time the pump will be stopped by pressing the STOP button located on the Waste Disposal Building MCC.

6. Check the level in the water collection tank, and calculate the amount of water transferred. 
7. Close and lock valves 54-24-109, Process Water Discharge to Ma in Condenser Hotwell, and 54-24-110, Process Water Discharge to Main Condenser Hotwell Shutoff. Notify the control room that transfer is complete.

8. Close valve 54-24-061, Water Collection Tank Outlet to Process Water Transfer Pump. The system is now back in normal operating configuration.

\subsubsection{Water Collection Tank Discharge to Standpipe}

Whenever the water in the tank is not desired for reuse or does not meet the primary water specification, it is discharged to the standpipe.

Prerequisites

1. The waste treatment building main floor section of the Liquid Waste Collection and Treatment Valve Checklist has been completed.

2. The process water transfer pump is ready for operation.

3. The liquid waste batch form has been prepared, and the water analysis confirms that the radioactivity level is such that it may be discharged to the standpipe.

4. The maximum rate of discharge has been determined, and the required dilution flow rate has been established.

5. The liquid waste and service water and the turbine condenser cooling water radiation monitors are in service.

Procedure

1. Open valves 54-24-061, Water Coll. Tank Outlet to Process Water Transfer Pump, 54-24-108, Process Water Outlet to River, and 54-24-026, Waste System Discharge to River.

2. Ensure that the liquid waste batch form has been properly filled out and that permission to discharge waste has been obtained from the shift supervisor.

3. Start the process water transfer pump by depressing the START button on the starter on the Waste Disposal Building MCC, and immediately establish the desired flow rate by opening valve 54-23-041, Flow Totalizer Outlet to Radiation Monitor, and by observing the flow indicator on the radiation monitor. 
4. Monitor the liquid radiation monitors during discharge; and, if either monitor alarms, stop discharging and determine cause of the alarm.

5. Allow the pump to operate until the pump stops automatically when the level in the water collection tank reaches $10 \mathrm{in}$. or by depressing the STOP button at the Waste Disposal Building MCC.

6. At completion of discharge, complete the liquid waste batch form, and notify the control room that discharge of waste has been completed. Flush lines and liquid waste radiation monitor in accordance with Sec. 5.4.34.

7. Return the system to normal by closing the following valves:

54-23-04 1, Flow Totalizer Outlet to Radiation Monitor

*54-24-026, Waste System Discharge to River

*54-24-108, Process Water Outlet to River

54-24-061, Water Coll. Outlet to Process Water Transfer Pump

8. Notify the control room that the system has been returned to normal.

\subsubsection{Concentrated Waste Tank Mixing and Recirculation}

Prerequisites

1. The waste treatment building basement section of the Liquid Waste Collection and Treatment Valve Checklist has been completed.

2. The concentrated waste pump is ready for operation.

3. The vent valve 55-24-004, Concentrated Waste Tank Vent, is open; and the stack blowers are in operation.

4. Electrical heaters on concentrated waste tank and piping are energized.

Procedure

1: Partially open valve 54-24-081, Conc. Waste Tank Station Sparge Air Inlet.

2. Open valves 54-24-058, Conc. Waste Transfer Pump Discharge, 54-24-102, Evap. Bottoms Outlet to Drumming Station, 54-24-120, Conc. Waste Transfer Pump Discharge to Drumming Station, and 54-24-103, Conc. Waste Tank Outlet to Transfer Pump Suction.

*denotes locked valve 
3. Set concentrated waste pump revolution counter to the number of revolutions equivalent to the volume desired to be circulated. See Fig. 5.4-7.

4. Start Conc. Waste Transfer Pump by pressing START button on START-STOPJOG control station located at the pump.

5. Monitor the Conc. Waste Transfer Pump discharge pressure (if there is no pressure, heating steam flushing is required).

(a) Close valve 54-24-081, Conc. Waste Tank, Station Sparge Air Inlet.

(b) Open valve 54-24-080, Conc. Waste Tank Heating Steam Sparge Inlet.

(c) Let steam flow until pump discharge pressure indicates that there is flow through the pump; then, shut off valve 54-24-080, Concentrated Waste Tank Sparge Steam Inlet, and open valve 54-24-081, Concentrated Waste Tank Sparge Inlet Station Air.

6. Let pump operate until it is tripped by the revolutions counter after the preset volume has been recirculated.

7. After recirculation is complete, close valves 54-24-081, Conc. Waste Tank Station Sparge Air Inlet, 54-24-102, Evap. Bottoms Outlet to Drumming Station, 5424-058, Conc. Waste Transfer Pump Discharge, 54-24-103, Conc. Waste Tank Outlet to Transfer Pump Suction, and 54-24-120, Conc. Waste Transfer Pump Discharge to Drumming Station. The system is now back in normal operating configuration.

\subsubsection{Preparation of Spent Resin Tank for Receiving Spent Resins from the Primary Purification System, Radwaste lon Exchanger, and Condensate Demineralizers}

Prerequisites

1. The waste treatment building sections of the Liquid Waste Collection and Treatment Valve Checklist have been completed.

2. The waste disposal building sump pumps breakers are closed, and the pumps are set up for AUTO operation with their capacity set for that of the tank into which they discharge. resin tanks.

3. Check the volume of spent resins that have been discharged into the spent

4. Stack blowers are in operation. 
LACBWR Operating Manual

April, 1968

Volume VII; Waste Collection and Treatment

Revised October, 1968

\section{Procedure}

1. Check the level of water in the spent resin tank sight glass gauge.

2. Open valve 54-23-004, Spent Resin Tank Drain to Sump.

3. Let the water drain for a period of time so that the maximum amount of water has been drained out of the spent resins in the tank. Close valve 54-23-004, Spent Resin Tank Drain.

4. Open valve 54-23-021, Spent Resin Tank Overflow Water Seal Drain, and let seal drain, then, close valve 54-23-021.

5. The spent resin tank is now properly set up to rece ive spent resins. Proceed to the appropriate procedure.

(a) LACBWR Operations Manual, Vol. VII, Sec. 5.4.28, Radwaste lon Exchange Spent Resin Transfer to Spent Resin Tank.

(b) Volume II, Sec. 6.4.5, Purification System Demineralizer Spent Resin Transfer to Spent Resin Tank.

(c) Volume III, Sec, 10.4 .3 .18, Exhausted Resin Transfer to Radwaste.

(d) Volume VII, Sec.5.4.35, Slurry Transfer to Spent Resin Tank from Waste Storage Tanks.

6. After the spent resins have been sluiced to the spent resin tank and the operations are completed, repeat steps 1,2,3, and 4 above to drain the excess water from the spent resin tank and to reset spent resin tank overflow alarm if it was actuated.

\subsubsection{Radwaste Ion Exchanger Spent Resin Transfer to Spent Resin Tank}

Prerequisites

1. The waste treatment building sections of the Liquid Waste Collection and Treatment Valve Checklist have been completed.

2. The preceding procedure 5.4.27 has been completed.

3. The water collection tank contains a sufficient quantity of demineralized water $(50 \mathrm{gal})$ for flushing the radwaste ion exchanger. 
LACBWR Operating Manual

Volume VII, Waste Collection and Treatment

April, 1968

Revised October, 1968

Procedure

1. Open the following valves:

54-24-062, Water Coll. Tank Outlet to Liquid Waste Demin. Pump

54-24-158, Water Coll. Tank Outlet

54-24-052, Neutralizer Eductor Water Supply

54-24-147, Neutralizer Eductor to Radwaste lon Exchanger

54-24-089, Radwaste Resin Outlet

2. Close the following valves:

54-24-105, Evap. Feed Tank Outlet

54-24-054, Eductor Discharge to Evap. Feed Tank

54-24-156, Evap. Feed Pump Recirc.

3. Connect the flexible air hose to the connection at valve 54-23-057, Sample and Resin Transfer, and open valve.

4. Open valve 54-24-157, Resin Transfer Air Conn., and pressurize the radwaste ion exchanger to not more than $15 \mathrm{psig.} \mathrm{Observe} \mathrm{that} \mathrm{the} \mathrm{resins} \mathrm{are} \mathrm{transferring} \mathrm{by}$ watching the bull's-eye in the resin transfer line.

5. After the bull's-eye is clear of resin, close valve 52-24-157, Resin Transfer Air Conn., and open valve 52-23-022, Radwaste lon Exchanger Vent.

6. Start the liquid waste demineral izer pump by depressing the START button on the Waste Disposal Building MCC, and transfer about $50 \mathrm{gal}$ of water from the water collecting tank to the radwaste ion exchanger.

7. After the water has been transferred, stop the pump by depressing the STOP button on the Waste Disposal Building MCC.

8. Close valve 54-23-022, Radwaste lon Exchanger Vent, and repeat steps 4 and 5 above. Transfer of resins is now completed.

9. Return system to normal by closing the valves listed in step 1 and by opening the valves listed in step 2 above.

\subsubsection{Radwaste lon Exchanger New Resin Loading}

The resins are sluiced from the chemical mix tank into the radwaste ion exchanger using the liquid waste demineralizer pump. When the eductor stops taking resins from the mix 
LACBWR Operating Manual

Volume VII, Waste Collection and Treatment
April, 1968

Revised October, 1968

tank, the pump is stopped; and the water is blown. from the exchanger to the water collection tank. This procedure is repeated until all the resins have been transferred.

Prerequisites

1.. The waste treatment building main floor section of the Liquid Waste Collection and Treatment Valve Checklist has been completed.

2. The liquid waste demineralizer pump is ready for operation.

3. Nine cubic feet of mixed resins, consisting of $3 \mathrm{ft}^{3}$ of cation and $6 \mathrm{ft}^{3}$ of anion resins, are available for filling the ion exchanger.

4. The water collection tank contains approximately $300 \mathrm{gal}$ of usable process water.

5. Resins have been transferred from the ion exchanger, and the exchanger is empty.

Procedure

1. Open the following valves:

54-24-062, Water Coll. Tank Outlet to Liquid Waste Demin. Pump

54-24-157, Water Coll. Tank Outlet

54-24-052, Neutralizer Eductor Water Supply

54-24-147, Neutralizer Eductor to Radwaste lon Exchanger

54-24-088, Radwaste Exch. Water Outlet

2. Close the following valves:

54-24-105, Evap. Feed Tank Outlet

54-24-054, Eductor Discharge to Evap. Feed Tank

54-24-156, Evap. Feed Pump Recir.

3. Connect the flexible air hose to the connection at valve 54-23-057, Sample and Resin Transfer, and open valve.

4. Open valve 54-24-158, Resin Transfer Air Conn.; pressurize the radwaste ion exchanger to not more than 15 psig, and blow water from the radwaste ion exchanger to the water collecting tank.

5. When the water level in the water collection tank stops rising, close valve 54-24-158, Resin Transfer Air Conn., and open valve 54-23-022, Radwaste lon Exchanger Vent. 
6. Place about $2 \mathrm{ft}^{3}$ of resin in the chemical mix tank, and cover it with demineralized water by opening valve 54-24-075, Chem. Mix Tank Demin. Water Supply, as required.

7. Start the liquid waste demineral izer pump by depressing the START button at the Waste Disposal Building MCC and immediately opening valve 54-24-053, Chem. Mix Tank Outlet to Neutralizer Eductor .

8. Operate the pump until the eductor stops taking resins. Then, immediately close valve 54-24-053, Chem. Mix Tank Outlet to Neutralizer Eductor, and stop the pump by depressing the STOP button located on the Waste Disposal Building MCC.

9. Repeat steps 4 through 8 above until all resins have been transferred .

10. Return system to normal by opening the valves listed in step 1 and by closing the valves listed in step 2 of this procedure.

11. Close valve 53-23-057, Sample and Resin Transfer, and disconnect flexible air hose. System is now back to normal .

\subsubsection{Evaporator Bottoms Discharge to Drumming Station}

Prerequisites

1. The waste treatment building sections of the Liquid Waste Collection and Treatment Valve Checklist have been completed. completed.

2. The evaporator bottoms are hot, and the evaporation operations have been

3. The electric piping heaters have been energized.

Procedure

1. Close valve 54-24-118, Conc. Waste Tank Inlet from Evap.

2. Open valves 54-24-102, Evap. Bottoms Outlet to Drumming Station, and 54-24-101, Evap. Bottoms Outlet.

3. Carry out Procedure 5.4.33, Concentrated Waste Drumming.

4. After operations are completed flush the lines as follows: 
LACBWR Operating Manual

Volume VII, Waste Collection and Treatment
April, 1968

Revised October, 1968

(a) Open the following valves:

54-24-067, Conc. Waste Transfer Pump Suction Inlet from Liquid Waste Demin. Pump

54-24-068, Conc: Waste Transfer Pump Suction from LP Service Water Line

54-24-1 45, Evap. Flushing Line

(b) Adjust valve 54-24-121, Evap.and Evap. Demister Flushing Water Inlet, until a flow of $10 \mathrm{gpm}$ is read on the line flow indicator. After $1 \mathrm{~min}$, close valve 54-24-121.

(c) Open valve 54-24-122, Drumming Station Waste Discharge, and let water drain into 55-gal drum; then, close valve 54-24-1 22.

(d) Close valve 54-24-102, Evap. Bottoms Outlet to Drumming Station.

(e): Open valve 54-24-118, Conc. Waste Tank. Inlet from Evap.

(f) Let drain, and then close val ve 54-24-101, Evap. Bottoms Outlet.

(g) Close valves 54-24-1 45, 54-24-067, and 54-24-068 that were opened in step 4 (a) above.

\subsubsection{Concentrated Waste Tank Discharge to Drumming Station}

Prerequisites

1. The waste treatment building basement sections of the Liquid Waste Collection and Treatment Valve Checklist have been completed.

2. Procedure 5.4.26, Concentrated Waste Tank Mixing and Recirculation, has been completed.

3. The concentrated waste has been monitored for its radioactivity level to determine the proper size of drums required. for the drumming operation.

4. The concentrated waste transfer pump is ready for operation.

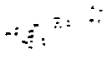

Procedure

1. Open valves 54-24-103, Conc. Waste Tank Outlet to Transfer Pump Suction, 54-24-058, Conc. Waste Transfer Pump Discharge, and 54-24-120, Conc. Waste Transfer Pump Discharge to Drumming Station . 
2. Carry out Procedure 5.4.33, Concentrated Waste Drumming.

3. After the drumming operations have been completed, flush the lines and return the system to normal as follows:

(a) Close valve 54-24-103, Conc. Waste Tank Outlet to Transfer Pump Suction.

(b) Open valve 54-24-068, Conc. Waste Transfer Pump Suction from LP Service Water Line.

(c) Open valve 54-24-122, Drumming Station Waste Discharge. gal).

(d) Set Concentrated Waste Pump Revolution Counter to 650 revolutions (10

NOTE: If pump has been shut down for an extended period, loosen by rotating shaft by hand, and then jog pump to insure free operation prior to operating unit .

(e) Start the waste transfer pump, and let operate until pump stops. (The flush water is being discharged into the 55-gal drum during pump operation.)

(f) Close the following valves:

54-24-122, Drumming Station Waste Discharge 54-24-120, Conc. Waste Transfer Pump Discharge to Drumming Station 54-24-058, Conc. Waste Transfer Pump Discharge

54-24-068, Conc. Waste Transfer Pump Suction from LP Service Water Line

\subsubsection{Spent Resin Discharge to Drumming Station}

Prerequisites

1. The waste treatment building sections of the Liquid Waste Collection and Treatment Valve Checklist have been completed.

2. The resins have been monitored for the ir radioactivity level to determine what size drums will be required for the drumming operation. 
LACBWR Operating Manual

\section{Procedure}

1. Open valve 54-24-077, Spent Resin Tank Station Air Inlet; then, throttle the valve until it is partially open.

2. Open valves 54-24-106, Spent Resin Tank Outlet, and 54-24-119, Spent Resin Tank Outlet to Drumming Station.

3. Carry out Procedure 5.4.33, Concentrated Waste Drumming.

4. After drumming operations are completed, flush the lines and return the system to normal as follows:

(a) Open valve 54-24-122; Drumming Station Waste Discharge .

(b) Slightly open valve 54-24-079, Spent Resin Tank LP Service Water Inlet. Let water flow for approximately $1 \mathrm{~min}(10-20 \mathrm{gal}$ of water flow). Than, close valve 54-24-079.

(c): Close the following valves:

54-24-122, Drumming Station Waste Discharge

54-24-077, Spent Resin Tank Station Air Inlet

54-24-106, Spent Resin Tank Outlet

54-24-119, Spent Resin Tank Outlet to Drumming Station

\subsubsection{Concentrated Waste Drumming}

Prerequisites

1. The waste treatment building sections of the Liquid Waste Collection and Treatment Valve Checklist have been completed.

2. Section 5.3.6, Drumming of Concentrated Waste, has been reviewed.

3. The concentrated waste transfer pump is ready for operation.

4. The concentrated waste to be drummed has been sampled and analyzed, and the drums to be used for drumming the waste to meet the requ irements of 10 CFR 20 have been selected.

5. Proper drums (55-gal, or 55-gal with 35-gal liner combination) are available to receive the waste. 
6. Cement and Vermiculite (cement grade) are available for drumming operations.

7. The radwaste drumming mixer is energized on the Waste Treatment Building MCC.

8. Health Physics coverage is available to monitor the drumming operations.

9. Stack blowers and the waste treatment building ventilation system are in operation.

Procedure

1. An empty 55-gal drum, or a 55-gal drum with 35-gal liner and concrete combination, is brought into the waste disposal building on the ground floor.

2. Forty-eight pounds of Vermiculite (two bags of cement grade) are added into the 55 -gal drum, or $30 \mathrm{lb}$ of Vermiculite are added into the 35-gal drum which is inside a 55gal concrete-lined drum.

3. The drum containing the concrete and Vermiculite is lowered through the hatch with the hoist, and it is placed on the dolly in the drumming station located immediately below the hatch.

4. Using the screw jack, the drum is clamped in position on the dolly by turning the handle protruding through the concrete block drumming station.

5. By manipulation of the jack handle, the dolly is then positioned with the drum centered beneath the mixer.

6. The appropriate mixing blade is inserted into the chuck of the mixing motor and is secured.

7. The valves in the system are set up in accordance with:

(a) Procedure 5.4.30, Evaporator Bottoms Discharge to Drumming Station, or

(b) Procedure 5.4.31, Concentrated Waste Tank Discharge to Drumming Station, or

(c) Procedure 5.4.32, Spent Resin Tank Discharge to Drumming Station.

8. The mixer is lowered to a point near the bottom of the drum . 
LACBWR Operating Manual

Volume VII, Waste Collection and Treatment

April, 1968

Revised October, 1968

9. Valve 54-24-122, Drumming Station Waste Discharge, is opened, and:

(a) If the waste is being added from the evaporator (in accordance with Procedure 5.4 .30 ), manually add approximately $30 \mathrm{gal}$ of liquid waste (or $19 \mathrm{gal}$ if the 35-gal drum is being used) to the dry Vermiculite, and close valve 54-24-122.

(b) If the waste is being added from the Concentrated Waste Tank (in accordance with Procedure 5.4.31), set the concentrated waste transfer pump revolution counter to cut off the pump at $30 \mathrm{gal}$ (1950 revolutions) for the $55-\mathrm{gal}$ drum, or at $19 \mathrm{gal}$ (1235 revolutions) if the 35 -gal drum is being used .

NOTE: If the pump has been shut down. for an extended period, loosen it by rotating the shaft by hand and then jogging the pump to ensure free operation prior to operating unit.

(c) Start the concentrated waste transfer pump by pressing the START button at the START-STOP-JOG control station located at the pump. The pump will be tripped by the revolution counter cut-off. Close valve 54-24-122.

(d). If the waste is being added from the Spent Resin Tank (in accordance with Procedure 5.4.32), manually add the resin slurry to the mixture as in (a) above.

10. After the drum has been filled to the appropriate level, start the mixer by pressing the START button located adjacent to the drumming station, and slowly raise and lower the mixer to obtain a good mixture.

11. Once the Vermiculite has been mixed with the liquid waste, lower the mixer to a point near the bottom of the drum.

12. Add one bag of cement $(94 \mathrm{lb})$, using the chute, and continue the mixing procedure by slowly raising and lowering the mixer until a homogeneous mixture is obtained, Extreme caution should be taken while raising the mixer to avoid spilling the mixture over the drum.

13. Lower the mixer to near the bottom of the drum, and add a second bag of cement for a total of $188 \mathrm{lb}$ (or $120 \mathrm{lb}$ for a 35 -gal drum). Continue the mixing procedure while slowly raising and lowering the mixer.

14. After a homogeneous mixture is obtained, slowly raise the mixer until the mixing blade is completely out of the mixture. Then, stop the mixer by pressing the STOP button located adjacent to the drumming station. 
LACBWR Operating Manual

April, 1968

Volume VII, Waste Collection and Treatment

Revised October; 1968

15. Carefully rinse the mixing blade, using the flexible hose connected to the LP service water at the drumming station. Avoid using too much water, and ensure that most of the rinse water and mixture particles on the blade fall into the waste drum.

NOTE: If more than one drum is to be mixed, the rinse operation will be delayed until all the mixing operations are completed. If the last drum is too full, use an empty drum to perform the blade rinsing operations.

16. Loosen the dolly-positioning jack screw, and move dolly and barrel from underneath the mixer; then, clean the sides of the drum with water as required.

17. The Health Physicist checks the drum to establish the radioactivity level, and the barrel is then lifted from the drumming station and loaded onto the grade floor.

18. If puddles of water remain on the surface, sprinkle dry cement over the top until the moisture is absorbed.

19. The Health Physicist again checks and labels the container.

20. The top of the barrel is placed in position and welded in place.

NOTE: For a 55-gal drum with 35-gal drum liner, the drum is first filled to the top with a cement cap; then, the cap is placed in position and welded in place.

21. The capped barrel is placed in the waste treatment building storage well or is removed for outside storage in a properly controlled area until it is shipped off site.

22. After the drumming operations have been completed, or at the end of the day, the system pipe lines that transferred the concentrated waste are flushed into a 55-gal drum so that the pipe lines will not become plugged with solidified, concentrated wastes. The system valves are then returned to normal operating configuration in accordance with:

(a) Procedure 5.4.30, Evaporator Bottoms Discharge to Drumming Station, or

(b) Procedure 5.4.31, Concentrated Waste Tank Discharge to Drumming Station, or

(c): Procedure 5.4.32, Spent Resin Tank Discharge to Drumming Station .

\subsubsection{Waste Water System Flushing}

After any liquid waste water discharge to the river whether from Waste Disposal Building, 
Retention Tanks, Waste Water Storage Tanks, or Change Room Drain Tank, flushing of the waste water lines from the waste water pump discharge through the waste water monitor is required to reduce the radiation levels in the pipes, both for personnel protection and to reduce the background as read on the Liquid Waste Radiation Monitor.

Prerequisites

1. Radioactive liquid waste has been discharged and system has been restored to normal, in accordance with the applicable procedure.

2. The gallonage discharged has been recorded on the Liquid Waste Batch Form.

Procedure

1. Open valves 54-24-176, LPSW Flush. Into 1A Disch . 54-24-025, IA Disch. to River/Retention; *54-24-026, Waste System Discharge to River .

Alternate: Open valves 54-24-177, LPSW Flush Into I B Disch ; 54-24-173, 1 B Disch. to River/Retention; *54-24-026, Waste System Discharge to River.

NOTE: The alternate valve path is to be used if the 1B transfer pump was used to discharge liquid waste to the river.

2. Commence flushing discharge piping and liquid waste monitor to the standpipe by opening valve 54-23-041, Flow Totalizer Outlet to Radiation Monitor; and observing the radiation monitor flow indicator to obtain $15 \mathrm{gpm}$. Continue for $5 \mathrm{~min}$.

3. Terminate flushing and restore system to normal by closing valves 54-24-176, LPSW Flush Into IA Disch .; 54-24-025, IA Disch 。 to River/Retention; *54-24-026, Waste System Discharge to River; 54-23-041, Flow Totalizer Outlet to Radiation Monitor.

Alternate: Close valves 54-24-177, LPSW Flush Into 1B Disch .; 54-24-173, 1B Disch. to River/Retention; 54-24-026, Waste System Discharge to River; and 54-23-041, Flow Totalizer Outlet to Radiation Monitor.

4. Record Liquid Waste Flow Totalizer reading on Liquid Waste Batch Form in appropriate space.

5. Notify control room, and verify that the liquid waste radiation monitor background has been restored to a normal reading.

*denotes locked valve 
LACBWR Operating Manual

Volume VII; Waste Collection and Treatment

April, 1968

Revised October, 1968

\subsubsection{Slurry Transfer to Spent Resin Tank from Waste Water Storage Tanks}

Over a period of time dirt, resin fines and other solids are accumulated on the bottom of the waste water storage tanks. This accumulation of radioactive semi-solids will be transferred to the spent resin tanks with the lB waste transfer pump.

The 3000-gal waste storage tank is pumped to the low level pump cut-off in accordance with applicable procedure. The internal standpipe is then removed and the slurry is pumped to the 4500 -gal waste water storage tank.

The 3000-gal waste water storage tank is returned to service, and the 4500 -gal waste water tank is then pumped to the spent resin tank until the low level pump cut-off is reached. The internal standpipe in the 4500-gal waste water storage tank is then removed, and the tank is pumped empty to the spent resin tank.

Prerequisites

1. The tunnel and waste water storage tanks area (el. $629 \mathrm{ft}$ ) section of the Liquid Waste Collection and Treatment Valve Checklist has been completed.

2. The 3000-gal waste water storage tank has been discharged in accordance with any of Procedures 5.4.10, 5.4.11 or 5.4.12.

3. Waste water transfer pump IB ready for operation.

4. The 3000-gal waste water storage tank has been isolated in accordance with steps 1,2 and 3 of Sec. 5.4.13, and manhole cover removed. Appropriate radiation and contamination surveys have been completed, and a special work permit has been filled out.

5. The standpipe in the 3000-gal waste water storage tank has been removed.

6. The 4500-gal waste water storage tank is ready to receive water and is less than 25 percent full.

7. The spent resin tank is lined up to receive the slurry in accordance with steps 1 through 5 of Sec. 5.4.27.

8. The condensate demineralizer must not be regenerated during this procedure.

Procedure

1. Open valve 54-24-169,3000-Gal Suction to 1B. 
2. Close valve 54-28-014, Low Level Pump Cut-Off Switches. Iso . from 3000-Gal Tank. Open 54-28-045, Low Level Pump Cut-O ff Switches. Iso . from 4500-Gal Tank.

3. Check open valve 67-24-062, Demin. $\mathrm{H}_{2} \mathrm{O}$ to $1 \mathrm{~B}$ Seal Iso .

4. Start IB waste water transfer pump by depressing the START button at the local pump control station. Observe that the pump is operating satisfactorily.

5. Throttle valve 54-24-175, .1B Recirc. and Inlet to $4500 \mathrm{Gal}$ to obtain a 50 psig discharge pressure.

6. With a hose connected to demineralized water, wash the slurry towards the suction pipe inside the tank. It may be necessary to stop the IB waste water transfer pump occasionally to keep the pump from running dry.

7. When the 3000 -gal waste water storage tank is clean of slurry, stop the IB waste water transfer pump by depressing to STOP button at the local pump control station.

8. Close valves 54-24-175, 1B Recirc and Inlet to 4500-Gal and 54-24-169, $3000-$ Gal Suction to 1B.

9. Re-install the standpipe in the 3000-Gal Waste Water Storage Tank and replace the manhole cover.

10. Restore the 3000-Gal Waste Water Storage Tank to service in accordance to step 4 of Sec. 5.4.13.

1.1. Isolate 4500-Gal Waste Water Storage Tank by closing valves 54-24-035, 4500-Gal Storage Tank 6-in。 Inlet and valve 54-24-037, 4500-Gal Storage Tank 4- In. Inlet, and opening valve 54-24-036, 3000-Gal Storage Tank 6-In. Inlet.

12. Open valve 54-24-170, 4500-Gal Suction to $1 \mathrm{~B}$.

13. Start IB Waste Water Transfer Pump by depressing START button at local control station. Throttle 54-24-171, IB Transfer Pump Disch. to Spent Resin Tank, to obtain 50 psig at pump discharge.

14. Drain Spent Resin Tank periodically to Waste Disposal Bldg. Sump by opening 54-23-014, Spent Resin Tank Drain to Sump; or allow the Spent Resin Tank to overflow to the sump. In both cases, water returns to 3000-Gall Waste Water Storage Tank. 
15. When 4500-Gal Waste Water Storage Tank is pumped to low-level pump cutoff and IB Waste Water Transfer Pump is stopped, close 54-28-045, Low-Level Pump Cutoff Switches Iso. from 4500-Gal Tank, and open valve 54-28-014, Low-Level Pump Cutoff Pump Switches Iso. from 3000-Gal Tank.

16. Open the 4500-Gal Waste Water Storage Tank by removal of the manhole cover.

17. Obtain radiation and contamination surveys and Special Work Permit and remove the standpipe inside the $4500-$ Gal Waste Water Storage Tank.

18. Start IB Waste Water Transfer Pump by depressing the START button at the local pump control station. Observe the bull's-eye sight-flow indicator in Waste Disposal Building for slurry transfer.

19. With a hose connected to demineralized water, wash the slurry towards the suction pipe inside the tank. It may be necessary to stop the pump occasionally to keep it from running dry.

20. When the $4500-G a l$ Waste Water Storage Tank is clean of slurry, stop the IB Waste Water Transfer Pump by depressing the STOP button at the local control station.

21. Close valve 54-24-170, 4500-Gal Suction to IB.

22. Flush out lines to Spent Resin Tank by opening Valve 54-24-177, LPSW Flush into IB Disch. until lines run clear by observing bull's-eye in Waste Disposal Building.

23. Close valves 54-24-177, LPSW Flush into IB Disch; and 54-24-171, 1B Transfer Pump to Spent Resin Tank.

24. Re-install the standpipe in the 4500-Gal Waste Water Storage:Tank, and replace the manhole cover $\therefore$... i i. $\therefore \quad \because \quad \because$.

25. Restore the 4500-Gal Waste Water Storage Tank by closing valve 54-24-036, 3000-Gal Storage Tank 6-In. Inlet. Open valve 54-24-035, 4500-Gal Storage Tank 6-In. Inlet; and valve 54-24-037, 4500-Gal Storage Tank 4-In。. Inlet。

26. Flush resin sluice line from condensate demineralizers by opening valves 63-24-031, Demin. Water to Condensate Demineralizers, and 63-24-027, Condensate Demineralizer Resin Out to Spent Resin Tank.

27. With the hand controller on the Condensate Demineralizer Panel, open valves 63-25-029, Demineralized Water and Anion Transfer Water Supply; and 54-25-031, Cation Tank Sluice Water. 
LACBWR Operating Manual

April, 1968

Volume VII, Waste Collection and Treatment

Revised October, 1968

28. When bull's-eye sight-flow indicator in Waste Disposal Building runs clear, close valves:

63-25-029, Demineralized Water and Anion Transfer Water Supply 63-25-031, Cation Tank Sluice Water

63-24-031, Demineralized Water Supply to System

63-24-027, Condensate Demineralizer Resin Out to Spent Resin Tank

29. Report to control room that 3000- and 4500-Gal Waste Water Storage Tanks and systems are restored to normal. 
LACBWR Operating Manual

Volume VII, Waste Collection and Treatment

\section{LIQUID WASTE COLLECTION AND TREATAAENT VALVE CHECKLIST}

VALVE NO.

NAME

POSITION

REACTOR BUILDING

$54-24-010$

$54-24-012$

$54-24-015$

$54-23-006$

$54-24-071$

$54-24-011$

54-24-013

54-23-007

$54-24-143$

54-24-072

$54-28-020$

54-28-047

54-24-069

$54-24-070$

54-24-014

54-23-047

54-28-027

54-23-046

54-24-016

54-24-017

$54-24-018$

$54-23-028$

54-23-030

54-23-038

$54-23-029$

54-23-035

54-23-031

54-23-036

54-23-037

54-23-045

$54-24-008$

54-24-009

54-28-025

$54-24-154$
Ret. Tank 1A Inlet

Ret. Tank IA Outlet

Ret. Tank IA Recirculation

Ret. Tank IA Sample

Ret. Tank TA Level Indic. Air Supply

Ret. Tank IB Inlet

Ret. Tank IB Outlet

Ret. Tank 1B Sample

Ret. Tank . IB Recirculation

Ret. Tank IB Level Indic. Air Supply

Ret. Tank IA Pump Cutoff Switch Isolation

Ret. Tank .1B Pump Cutoff Switch Isolation

Portable Demin. Inlet

Portable Demin. Outlet

Ret. Tanks Pumps Discharge

Ret. Tanks Pump Drain

Ret. Tanks Pump Discharge Press. Ind. Isolation

Ret. Tanks Pump Vent and Sample

Ret. Tanks Pump Discharge to Evap. Feed Tank or

Radwaste lon Exch.

Ret. Tanks Pump Discharge to River or Waste Storage Tanks

Outside Sump Pumps Discharge to Retention Tank

Fuel Storage Well Water Seal Drain

Overhead Storage Tank Drain Water Seal Drain

Upper Cavity Expansion Joint Drain Loop Seal Drain

Upper Cavity Water Seal Drain

Upper Cavity Water Seal Vent

Lower Cavity Drain Water Seal Drain

Target Plate Drain Water Seal Drain

Target Plate Drain Water Seal Vent

Upper Cavity and Seal Injection Reservoir Lower Loop Seal Drain

Reactor Building Sump Pump IA Discharge

Reactor Building Sump Pump 1B Discharge

Reactor Building Sump Pumps Discharge Pressure

Indicator Isolation

Valve 54-25-006 A ir Supply

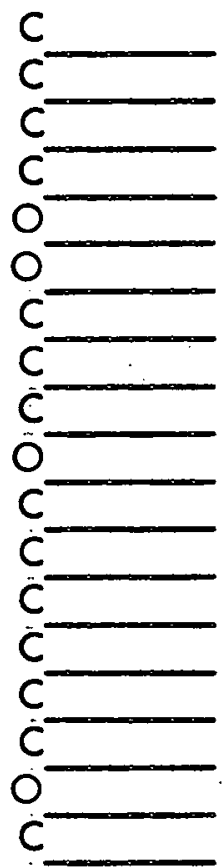

LC

LC

LC

C

C

C

C

C

C

C

C

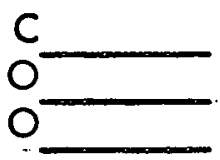

0

0 
Liquid Waste Collection and Treatment Valve Checklist (cont'd)

VALVE NO. NAME

POSITION

TURBINE BUILDING

$54-24-168$

$54-24-165$

$54-23-164$

54-23-066

54-23-065

$54-28-048$

$54-28-049$

$54-23-067$

$54-28-050$

$54-28-051$

$54-23-068$

$54-24-146$

$54-23-041$

54-23-040

$54-23-042$

$54-24-074$

$54-23-043$

$54-24-126$

$54-24-.127$

$54-24-155$
Turbine Building Sump Pumps Discharge to Standpipe Change Room Drain Tank Transfer Pump Discharge Change Room Drain Tank Recirculation Change Room Drain Tank Sample

Change Room Drain Tank Drain

Change Room Drain Tank Overflow Alarm Switch Upper Isolation

Change Room Drain Tank Overflow Alarm Switch Lower Isolation

Change Room Drain Tank Overflow Alarm Switch Drain

Change Room Drain Tank Hi Level Alarm Switch Upper Isolation

Change Room Drain Tank Hi Level Alarm Switch Lower Isolation

Change Room Drain Tank Hi Level Alarm Switch

Drain

Flow Totalizer Outlet to Standpipe

Flow Totalizer Outlet to Radiation Monitor

LP Service Water to Radiation Monitor

Gen. Plant Sump Pump to Radiation Monitor

Liquid Waste and Service Water Radiation Monitor Outlet

Turbine Cond. Cooling Water Radiation Monitor Sample

Turbine Cond. Cooling Water Radiation Monitor Inlet

Turbine Cond. Cooling Water Radiation Monitor

Outlet

Turbine Cond. Cooling Water Radiation Monitor.

Eductor Supply
LC

C

$\dot{C}$

$\overline{\mathrm{C}}$

C

O

O

C

O

O

C

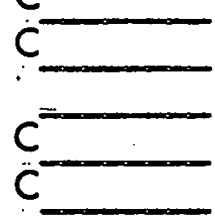

O

C

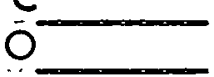

$\mathrm{O}$

$\mathrm{T}$

LC

LC

LC

LC

C
Process Water Outlet to River

Process Water Discharge to Main Cond. Hotwell

Process Water Discharge to Main Cond. Hotwell
Waste System Discharge to River

$54-24-025$

54-24- 109

$54-24-110$ 
Liquid Waste Collection and Treatment Valve Checklist (cont'd)

VALVE NO.

$54-24-024$

$54-24-023$

$54-24-029$

$54-24-030$

$54-24-153$

$54-24-152$

54-23-051

$54-23-052$

$54-28-026$

54-23-039

54-24-036

$54-24-032$

$54-28-016$

54-28-015

$54-23-008$

$54-23-024$

54-28-001

54-28-002

54-23-015

54-28-013

54-28-014

54-28-045

54-23-032

54-24-035

54-24-037

54-23-023

54-24-031

54-28-018

54-24-169

54-24-170

54-23-069

54-23-070

54-24-071

54-24-176

54-24- 177
NAME

POSITION

1A Discharge to Evap. Feed Tank or Radwaste lon Exch.

Storage Tanks Transfer Pump Discharge to Ret. Tanks 1A Recirc. and Inlet to $4500 \mathrm{Gal}$

IA Recirc. and Inlet to $3000 \mathrm{Gal}$

3000-Gal Tank Inlet from Turbine Bldg., Waste

Treatment Bldg。 and Gas Vault Sumps

(3 in.) 3000-Gal Tank Inlet from Waste Treatment

Bldg. and Gas Vaults Sumps

1A Transfer Pump Vent

1A Transfer Pump Drain

IA Transfer Pumps Disch Pres Ind Iso

IA Pump Disch Sample

3000-Gal Storage Tank 6-In. Inlet

$3000-$ Gal Suction to IA

3000-Gal Tank Hi Level Switch Lower Isolation

3000-Gal Tank Hi Level Switch Upper Isolation

3000-Gal Tank Hi Level Switch Drain

3000-Gal Tank 6-In. Inlet Water Seal Drain

3000-Gal Tank Sight Glass Upper Isolation

3000-Gal Tank Sight Glass Lower Isolation

3000-Gal Tank Sight Glass Drain

Low Level Pump Cutoff Switches Vent

Low Level Pump Cutoff Switches Iso from 3000-Gal

Tank

Low Level Pump Cutoff Switches Iso from 4500-Gal

Tank

Low Level Pump Cutoff Switches Drain

4500-Gal Storage Tank 6-In. Inlet.

4500-Gal Storage Tank 4-ln. Inlet

4500-Gal Tank 6-In. Inlet Water Seal Drain

4500-Gal Suction to $1 A$

4500-Gal Tank Hi Level Switch Lower Isolation

3000-Gal Suction to IB

4500-Gal Suction to IB

IB Transfer Pump Vent

1B Transfer Pump Drain

IB Transfer Pump Sample

LPSW Flush Into IA Disch.

LPSW Flush into IB Disch.

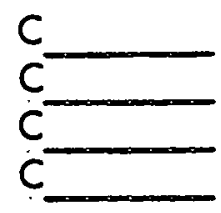

O

O

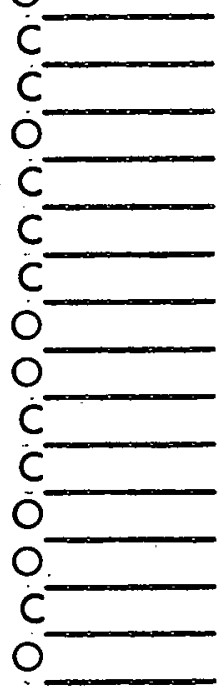

O

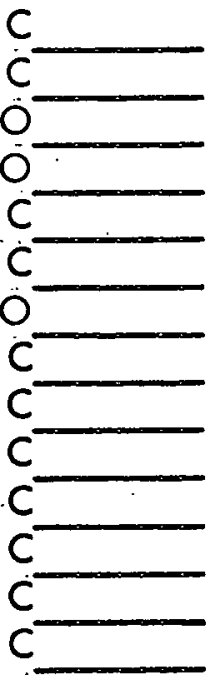


LACBWR Operating Manual

Volume VII, Waste Collection and Treatment
April, 1968

Revised October, 1968

Liquid Waste Collection and Treatment Valve Checklist (cont $\left.{ }^{\prime} d\right)$

VALVE NO.

NAME

POSITION

$54-24-173$

$54-24-174$

$54-24-175$

$54-24-171$

$54-24-172$

$54-24-178$

$54-24-179$

$54-24-180$

$67-22-024$

67-24-062

54-28-017

54-23-009

54-28-003

$54-28-004$

$54-23-016$

$54-23-064$

$54-24-160$

54-23-060

$54-24-162$

$54-23-062$

$54-24-161$

$54-23-061$

$54-24-166$

$54-24-167$

$54-24-163$

IB Disch.to River/Retention

IB Recirc. and Inlet to $3000 \mathrm{Gal}$

IB Recirc, and Inlet to $4500 \mathrm{Gal}$

IB Transfer Pump to Spent Resin Tank

IB to Evap. Feed Tank/Radwaste lon Exch 。

Waste System Disch. to River Iso.

Waste/Retention Systems Cross-Connect

Waste/Retention Systems Hose Connection

Demin. $\mathrm{H}_{2} \mathrm{O}$ to IB Seal

Demin. $\mathrm{H}_{2} \mathrm{O}$ to .1B Seal iso.

4500-Gal Tank Hi Level Switch Upper Isolation

4500-Gal Tank Hi Level Switch Drain

4500-Gal Tank Sight Glass Upper Isolation

4500-Gal Tank Sight Glass Lower Isolation

4500-Gal Tank Sight Glass Drain

4500-Gal Tank Sight Glass Vent

Retention Tanks to Evap Feed Tank Containment

External Isolation

Retention Tanks to Evap Feed Tank Containment Test

Sump Pumps Header Containment External Isolation

Sump Pumps Header Containment Test

Retention Tanks to River Containment External Iso.

Retention Tanks to River Containment Test

Turbine Plant Sump Pump IA Discharge

Turbine Plant Sump Pump 1B Discharge

Tunnel Ejector Pump Discharge

C

C

C

$\mathrm{C}$

C

0

0

$\mathrm{C}$

(SOLENOID)

O

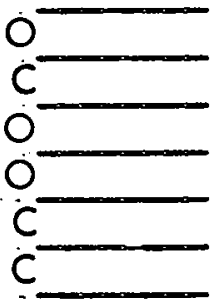

0

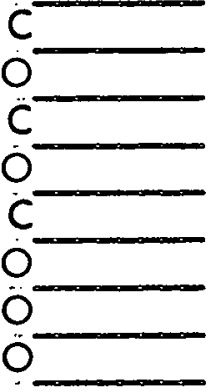

WASTE GAS STORAGE VAULT

54-24-041 Waste Gas Storage Vault Sump Pump IA Discharge

54-24-042 Waste Gas Storage Vault Sump Pump IB Discharge

$54-28-024$

Waste Gas Storage Vault Sump Pumps Discharge

Pressure Indicator Isolation

O

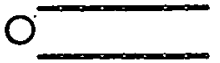

$\mathrm{O}$

WASTE DISPOSAL BUILDING MAIN FLOOR

54-24-075 Chem. Mix Tank Demin Water Supply

$54-28-007$

Chem. Mix Tank Sight G lass Upper Isolation

$54-28-008$

Chem. Mix Tank Sight Glass Lower Isolation

54-23-018

Chem. Mix Tank Sight Glass Drain

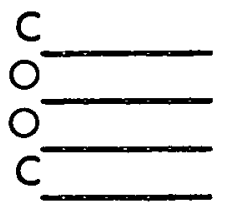


LACBWR Operating Manual

Volume VII, Waste Collection and Treatment

April, 1968

Revised October, 1968

Liquid Waste Collection and Treatment Valve Checklist (cont'd)

VALVE NO.

$54-24-053$

54-23-001

$54-24-052$

$54-24-054$

$54-24-147$

$54-24-045$

54-23-005

$54-23-003$

$54-24-157$

$54-24-061$

54-24-062

54-28-036

54-28-037

54-28-009

54-28-010

54-28-019

54-28-028

$54-24-065$

54-24-064

54-24-048

54-24-049

54-28-030

$54-24-046$

54-24-047

54-23-053

54-23-054

54-28-029

$54-24-124$

54-24-156

54-24-050
NAME

Chem. Mix Tank Outlet to Neutralizer Eductor

Chem. Mix Tank Outlet to Waste Disposal Building

Sump

Neutralizer Eductor Water Supply

Neutralizer Eductor Discharge to Evap Feed Tank

Neutralizer Eductor Discharge to Radwaste lon

Exchanger

Water Coll Tank Inlet from Radwaste Exch

Water Coll Tank Sample

Water Coll Tank Drain to Waste Disp. Building Sump

Water Coll Outlet

Water Coll Tank Outlet to Process Water Transfer

Pump

Water Coll Tank Outlet to Liquid Waste Demin. Pump

Water Coll Tank Level Indicator Upper Isolation

Water Coll Tank Level Indicator Lower Isolation

Water Coll Tank Sight. Glass Upper Isolation

Water Coll Tank Sight Glass Lower Isolation

Water Coll Tank Sight Glass Drain

Process Water Pump Discharge Pressure Indicator Isolation

Process Water Pump Discharge to Main Condenser Hotwell and River

Process Water Pump Discharge to Evap Feed Tank, Evap Demister, and Concentrated Waste Transfer Pump Suction

Evap Feed Pump Suction

Evap Feed Pump Discharge

Evap Feed Pump Discharge Pressure Indicator

Isolation

Liquid Waste Demin. Pump Suction

Liquid Waste Demin. Pump Discharge

Liquid Waste Demin. Pump Vent

Liquid Waste Demin. Pump Drain

Liquid Waste Demin. Pump Discharge Pressure

Indicator Isolation

Evap Feed and Liquid Demin. Pumps Discharge to

Evap Feed Tank, Evap Demister, and Conc. Waste

Transfer Pump Suction

Evap Feed Pump Recirc

Evap Feed Pump and Liquid Demin Pump Discharge to Radwaste Ion Exch
POSITION

C

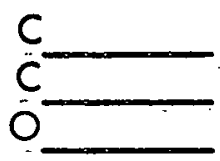

C
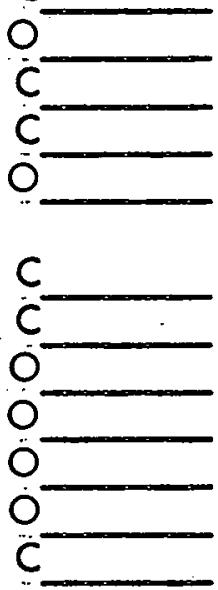

O

O

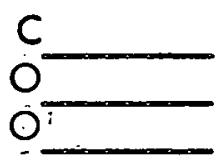

0

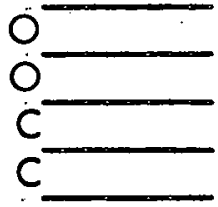

O

C

C

C 
LACBWR Operating Manual

Volume VII, Waste Collection and Treatment

April, 1968

Revised October, 1968

Liquid Waste Collection and Treatment Valve Checklist (cont ${ }^{\mathrm{d}} \mathrm{d}$ )

VALVE NO.

$54-23-057$

$54-24-051$

$54-24-055$

$54-25-005$

$54-24-056$

$54-24-057$

$54-25-018$

$54-24-139$

$54-24-125$

$54-24-140$

$54-24-141$

54-24-142

54-23-063

54-24-138

54-24-136

54-24- 158

$54-24-135$

54-24-083

$54-24-137$

54-28-040

54-28-041

54-24- 121

$54-24-145$

54-24-144

54-24-101

54-23-011

54-24-.102

54-23-002

54-24-105

54-24-013

54-24-044

54-24-076

54-24-066

54-24-043

54-24-104

54-28-034
NAME

Sample and Resin Transfer Air Conn.

Evap Feed Pump and Liquid Demin Pump Discharge

to Evaporator

Evaporator Inlet Flow Control Valve. Inlet

Evaporator Inlet Flow Control

Evaporator Inlet Flow Control Valve Outlet

Evaporator Inlet Flow Control Valve Bypass

Evaporator Heating Steam Supply

Evap Heating Steam Supply Control Valve Outlet

Press Sensor Isolation

Evap Heating Steam Supply Control Valve Bypass

Evap Steam Cond Trap Inlet

Evap Steam Cond Trap Outlet

Evap Steam Cond Trap Bypass

Evap Steam Cond Return Drain

Evap Hi Level Transmitter Control Air Supply

Evap Vapor Chamber Pressure Transmitter Control

Air Supply

Resin Loading Air Supply

Evap Steam Pressure Transmitter Control Air Supply

Evap Level Control Air Supply

Evap Low Level Transmitter Control Air Supply

Evap Steam Pressure Transmitter Isolation

Evap Vapor Chamber Pressure Transmitter Isolation

Evap and Evap Demister Flushing Water Inlet

Evap Flushing Line

Demister Flushing Line

Evap Bottoms Outlet

Evap Bottoms Sample

Evap Bottoms Outlet to Drumming Station

Evap Feed Tank Drain to Waste Disp. Building Sump

Evap Feed Tank Outlet

Evap Feed Tank Sample

Evap Feed Tank Inlet from Radwaste Exch

Evap Feed Tank Station A ir Inlet

Evap Feed Tank Inlet from Process Transfer Pump,

Liquid Demin Pump and LP. Service Water Supply

Evap Feed Tank Inlet from Retention and Waste

Storage Tanks

Evap Feed Tank Inlet from Conc Waste Tank

Evap Feed Tank Level Indicator Upper Inlet Isolation
POSITION

C

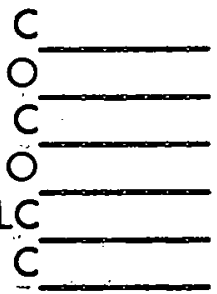

O

LC

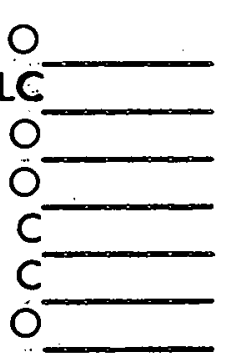

O

C

O

O

0

O

O

$\mathrm{C}$

T

T

$\mathrm{C}$

C

C

C

$\ddot{0}$

C

C

C

C

0

C

C

$=$

O 
Liquid Waste Collection and Treatment Valve Checklist (cont'd)

VALVE NO.

$54-28-035$

$54-28-011$

$54-28-012$

$54-23-020$

$54-24-085$

$54-24-086$

$75-24-018$

54-23-010

$54-23-003$

54-23-004

$54-24-087$

$54-24-088$

$54-24-089$

$54-28-032$

$54-23-034$

$54-28-033$

$54-24-132$

54-24- 134

54-28-038

54-28-039

54-28-042

54-28-043

54-23-022

$54-24-100$

54-24-077

54-24-079

54-24-078

54-24-106

54-24-119

54-23-014

54-23-004

54-24-107

54-28-005

54-28-006

54-23-017

54-28-02 1

54-28-022

54-23-026

54-23-021
NAME

Evap Feed Tank Level Indicator Lower Inlet Isolation

Evap Feed Tank Sight Glass Upper Inlet

Evap Feed Tank Sight Glass Lower Inlet

Evap Feed Tank Sight Glass Drain

Evap Condenser Cooling Water Inlet

Evap Condenser Cooling Water Outlet

Evap Condenser Cooling Water Outlet to Service

Water Hdr.

Evap Condenser Tube Drain

Evap Condenser Shell Side Vent (Steam)

Evap Condenser Tube Side Vent. (Cooling Water)

Radwaste Exch Water Inlet

Radwaste Exch Water Outlet

Radwaste Resin Outlet

Radwaste Press Diff. Trans. Hi Pressure Isolation

Radwaste Outlet Drain to Sump

Radwaste Press Diff. Trans. Low Pressure Isolation

Radwaste Press Diff. Trans. Control Air Supply

Radwaste Exch Flow Trans. Control Air Supply

Radwaste Exch Flow Trans HP Isolation

Radwaste Exch Flow Trans LP Isolation

Radwaste Exch Inlet Cond Cell Isolation

Radwaste Exch Outlet Cond Cell Isolation

Radwaste Exch Vent

Spent Resin Tank Inlet from Evap Feed Pump

Spent Resin Tank Station Air Inlet

Spent Resin Tank LP Service Water Inlet

Spent Resin Tank LP Service Water Supply

Spent Resin Tank Outlet

Spent Resin Tank Outlet to Drumming Station

Spent Resin Tank Sample

Spent Resin Tank Drain to Sump

Spent Resin Tank Overflow

Spent Resin Tank Sight Glass Upper Inlet

Spent Resin Tank Sight Glass Lower Inlet

Spent Resin Tank Sight Glass Drain

Spent Resin Tank Overflow Water Seal Level Switch Upper Inlet

Spent Resin Tank Overflow Water Seal Level Switch Lower Inlet

Spent Resin Tank Overflow Water Seal Level Switch

Drain

Spent Resin Tank Overflow Water Seal Drain
POSITION

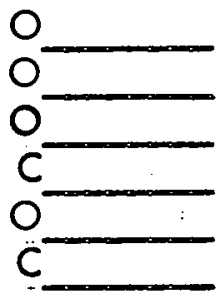

LO

C

C

C

c

c

C

O

C

O

O

Ó

O

Ó

O

C

C

C

C

C

C

C

C

$C$

O

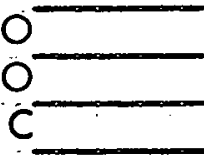

O

0

C

C 
LACBWR Operating Manual

Volume VII, Waste Collection and Treatment
April, 1968

Revised October, 1968

Liquid Waste Collection and Treatment Valve Checklist (cont'd)

VALVE NO.

NAME

POSITION

WASTE DISPOSAL BUILDING BASEMENT

$54-24-118$

$54-24-081$

$55-24-004$

$54-24-080$

$54-23-012$

$54-24-103$

$54-24-058$

$54-23-055$

54-23-056

54-24-059

$54-28-031$

$54-24-133$

$54-24-128$

$54-28-044$

$54-24-068$

$54-24-067$

$54-24-.120$

$54-24-122$

$54-24-060$

$54-24-063$

$54-24-039$

$54-24-040$

$54-28-023$

$54-24-159$

54-23-059

54-23-058
Conc. Waste Tank Inlet from Evap (Bottoms)

Conc. Waste Tank Station Sparge Air Inlet

Conc. Waste Tank Vent to Off-Gas

Conc. Waste Tank Heating Steam Sparge Inlet

Conc. Waste Tank Sample

Conc. Waste Tank Outlet to Transfer Pump Suction

Conc. Waste Transfer Pump Discharge

Conc. Waste Transfer Pump Vent

Conc. Waste Transfer Pump Drain

Conc. Waste Transfer Pump Bypass

Conc. Waste Pump Discharge Press Indicator Isolation

Conc. Waste Pump Discharge Press Trans. Air Supply

Conc. Waste Tank Level Indicator Air Supply

Conc. Waste Tank Level Indicator Isolation

Conc. Waste Transfer Pump Suction from LP Service Water

Conc. Waste Transfer Pump Suction Inlet from

Liquid Waste Demin Pump

Conc. Waste Transfer Pump Discharge to Drumming

Station

Drumming Station Waste Discharge

Spent Resin Tank Outlet to Evap Feed Tank

Drumming Station LP Service Water Outlet

Waste Disp. Building Sump Pump IA Discharge

Waste Disp. Building Sump Pump 1B Discharge

Waste Disposal Building Sump Pump Discharge

Pressure Indicator Isolation

Radwaste lon Exch. Sluice Line Blowdown

Spent Resin Tank Drain Shutoff

Spent Resin Tank Drain Strainer Backflush

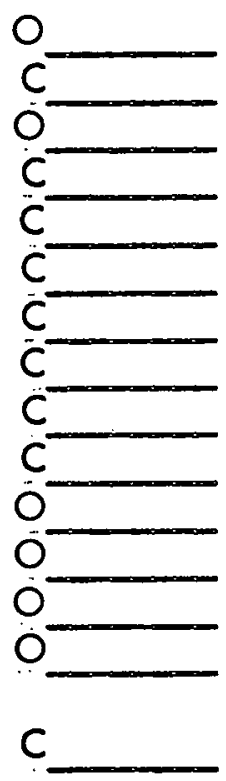

C

$\mathrm{C}$

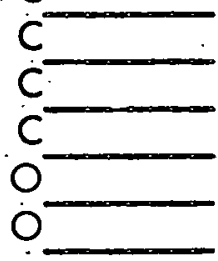

0

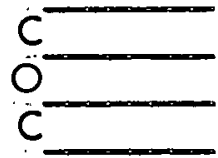

DATE TIME SHIFT SUPERVISOR

\section{LEGEND:}

$$
\begin{aligned}
C & =\text { Closed } \\
O & =\text { Open } \\
T & =\text { Throttled } \\
L C & =\text { Locked Closed } \\
L O & =\text { Locked Open }
\end{aligned}
$$


LACBWR Operating Manual

Volume VII, Waste Collection and Treatment
April, 1968

Revised October, 1968

NO.

\section{LIQUID WASTE BATCH FORM}

Liquid waste discharge to standpipe from tanks。

\section{LABORATORY ANALYSIS}

\begin{tabular}{|l|l|}
\hline Source of Sample & \\
\hline Gallons in Tank & \\
\hline Recirc. Time & \\
\hline Time and Date of Sample & \\
\hline Conductivity & \\
\hline pH & \\
\hline Activity $\mu c / c c$ & \\
\hline Recommended Disc. Rate with & \\
\hline
\end{tabular}

\section{SHIFT SUPERVISOR}

\begin{tabular}{|l|l|}
\hline Time \& Date & \\
\hline Pumps Required & \\
\hline Circulating Water Flow (gpm) & \\
\hline Tank Disch. Rate & \\
\hline Lig. Waste Monitor Bkg. (cpm) & \\
\hline Liq. Waste Monitor Alarm Point (cpm) & \\
\hline
\end{tabular}

\section{OPERATOR}

Date of Discharge

Flow Totalizer Reading Start

Tank Level Start

Time Start

Discharge Rate (gpm)

Time Finish

Tank Level Finish

Flow Totalizer Reading

Circulating Flow During Disch.

Liq. Waste Monitor Reading (cpm)

Total Gallons Discharged 


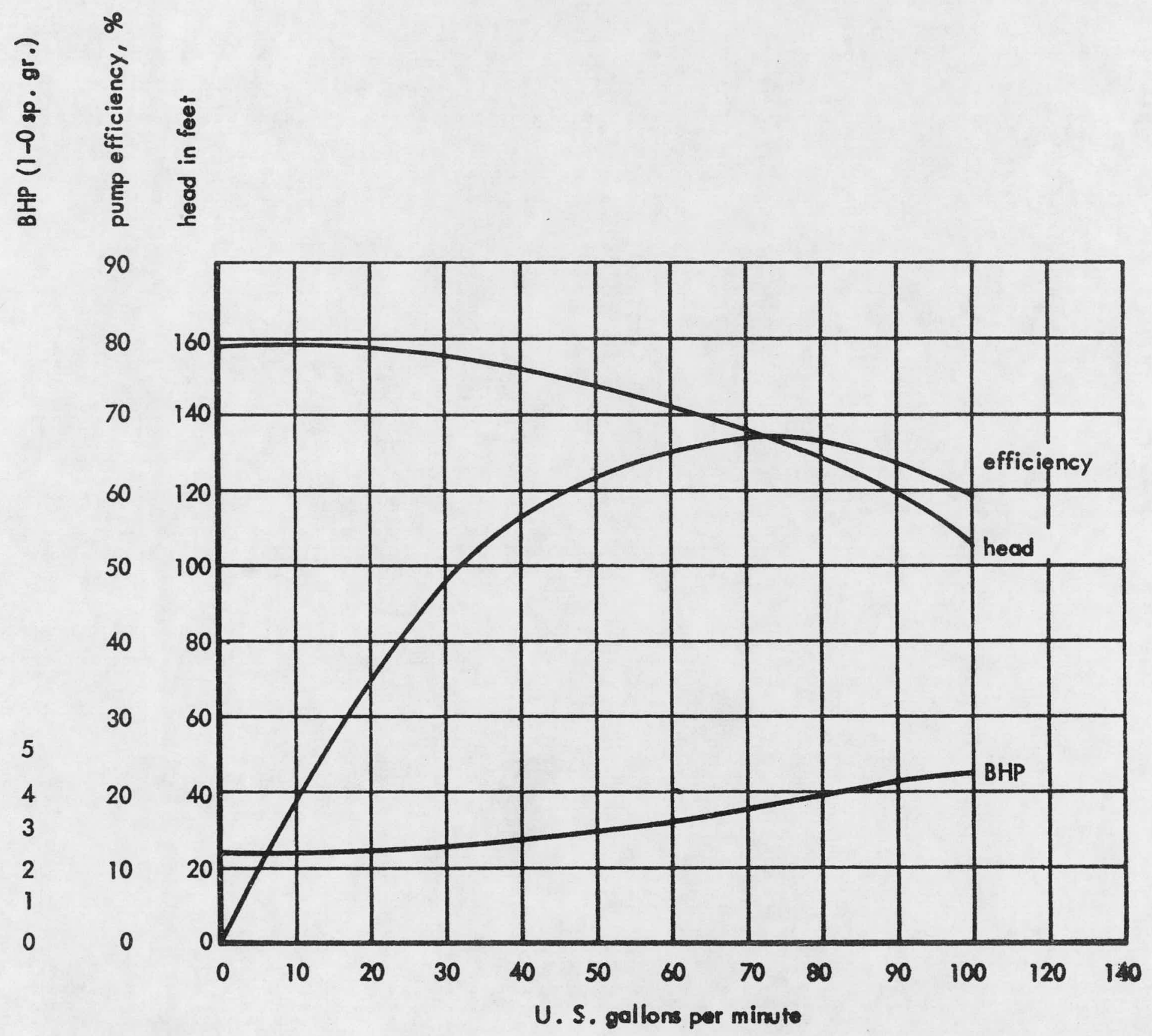




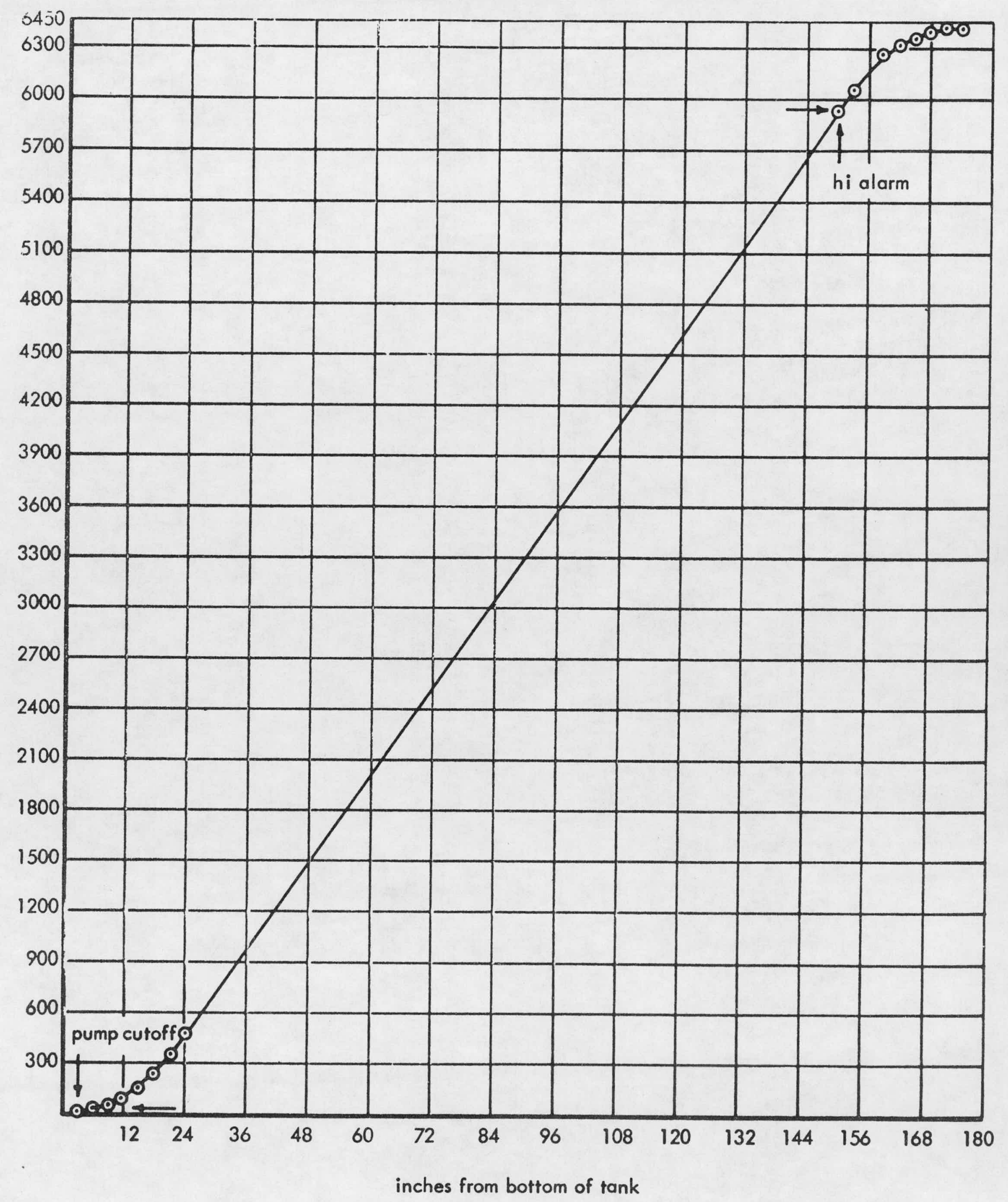




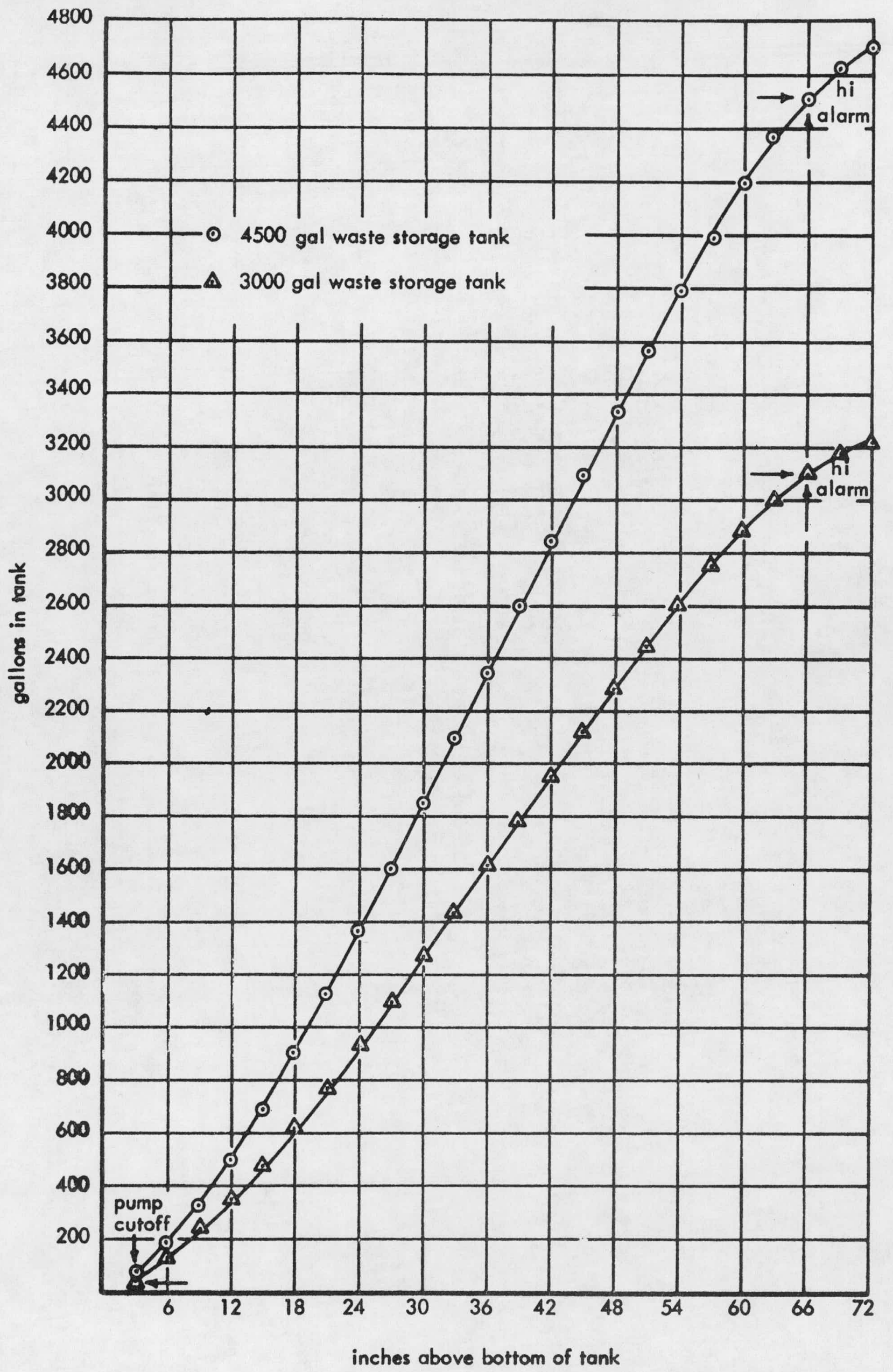




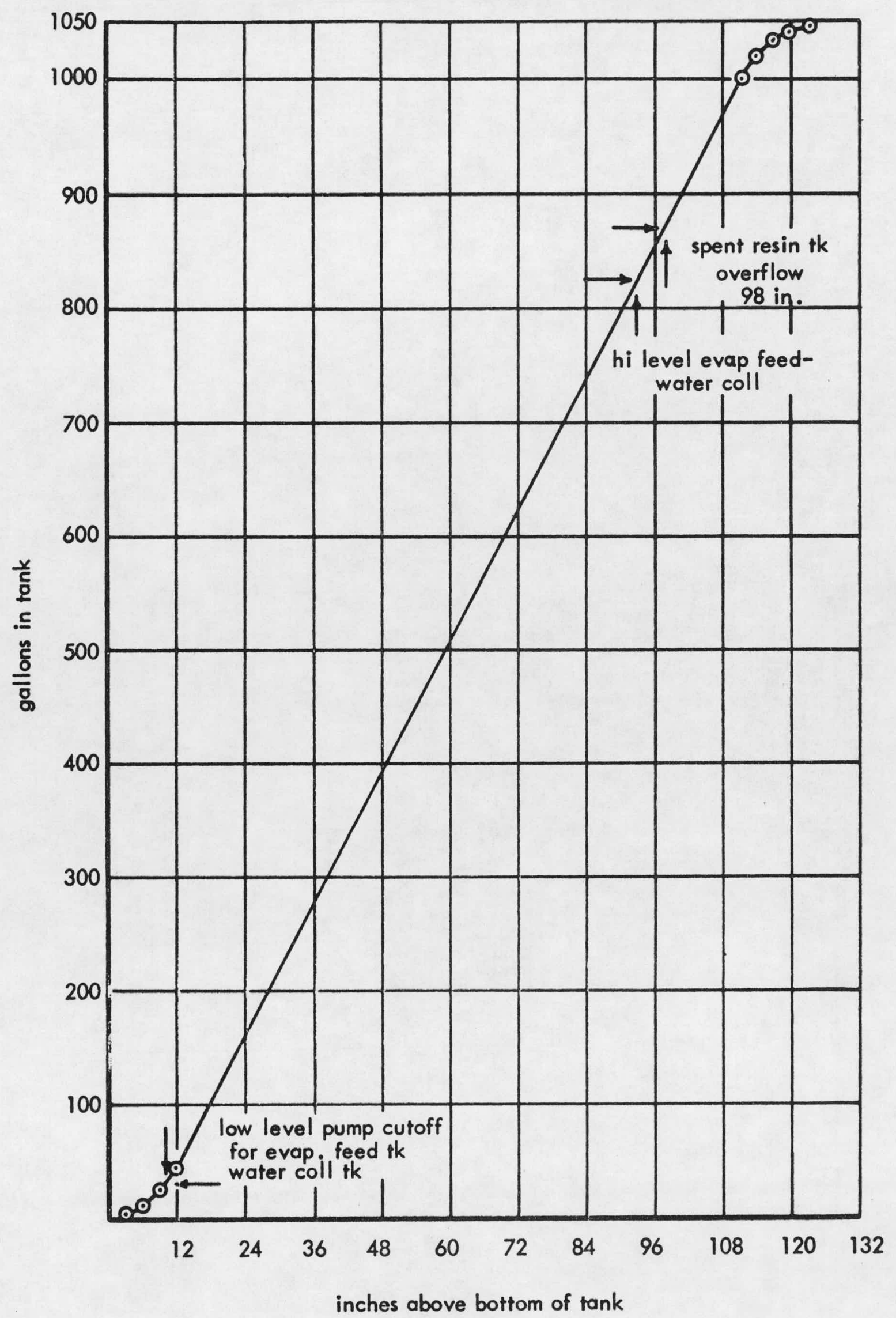

EVAPORATOR FEED TANK, WATER COLLECTION TANK, AND SPENT RESIN TANK

FIG 5.4-5 


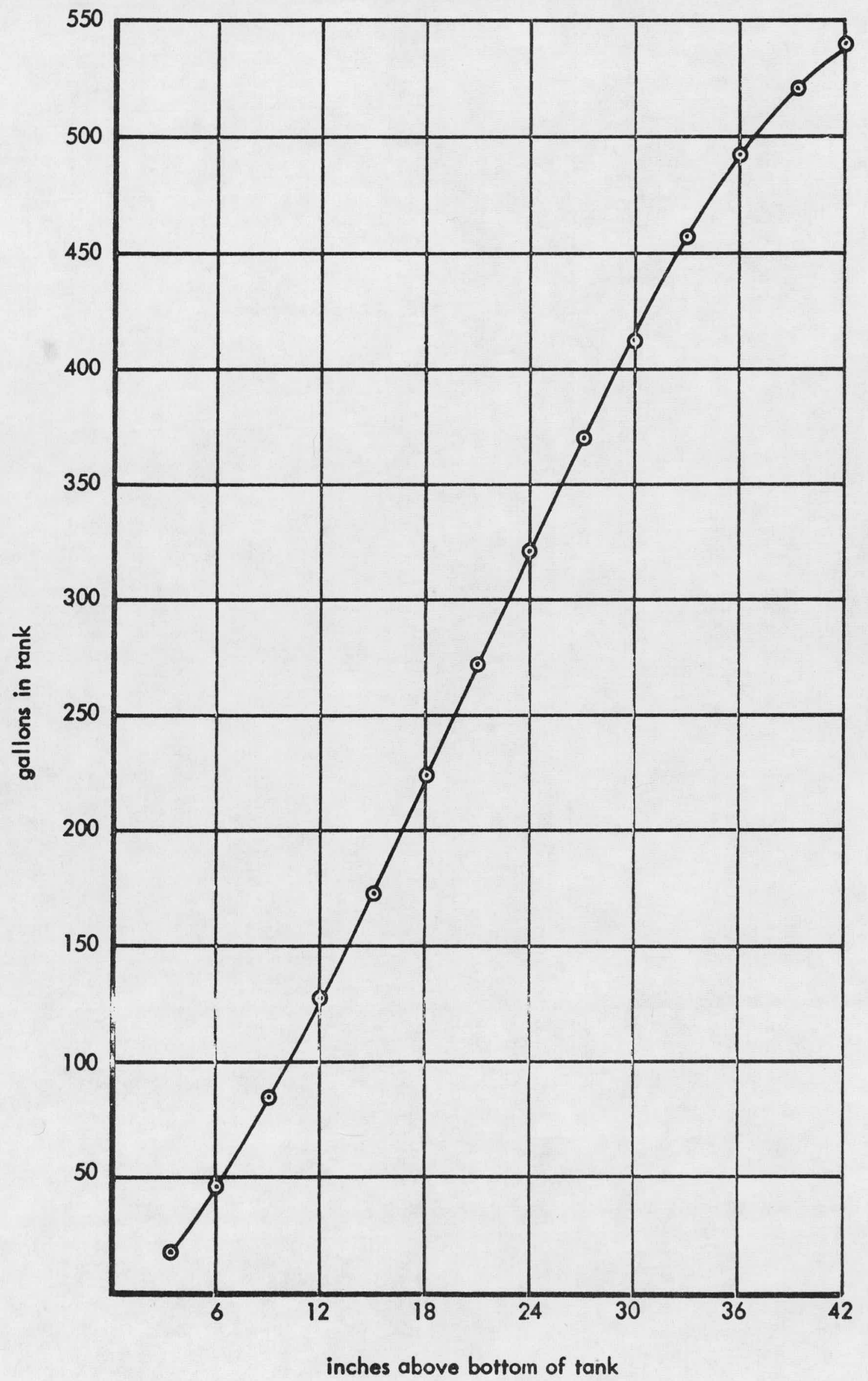




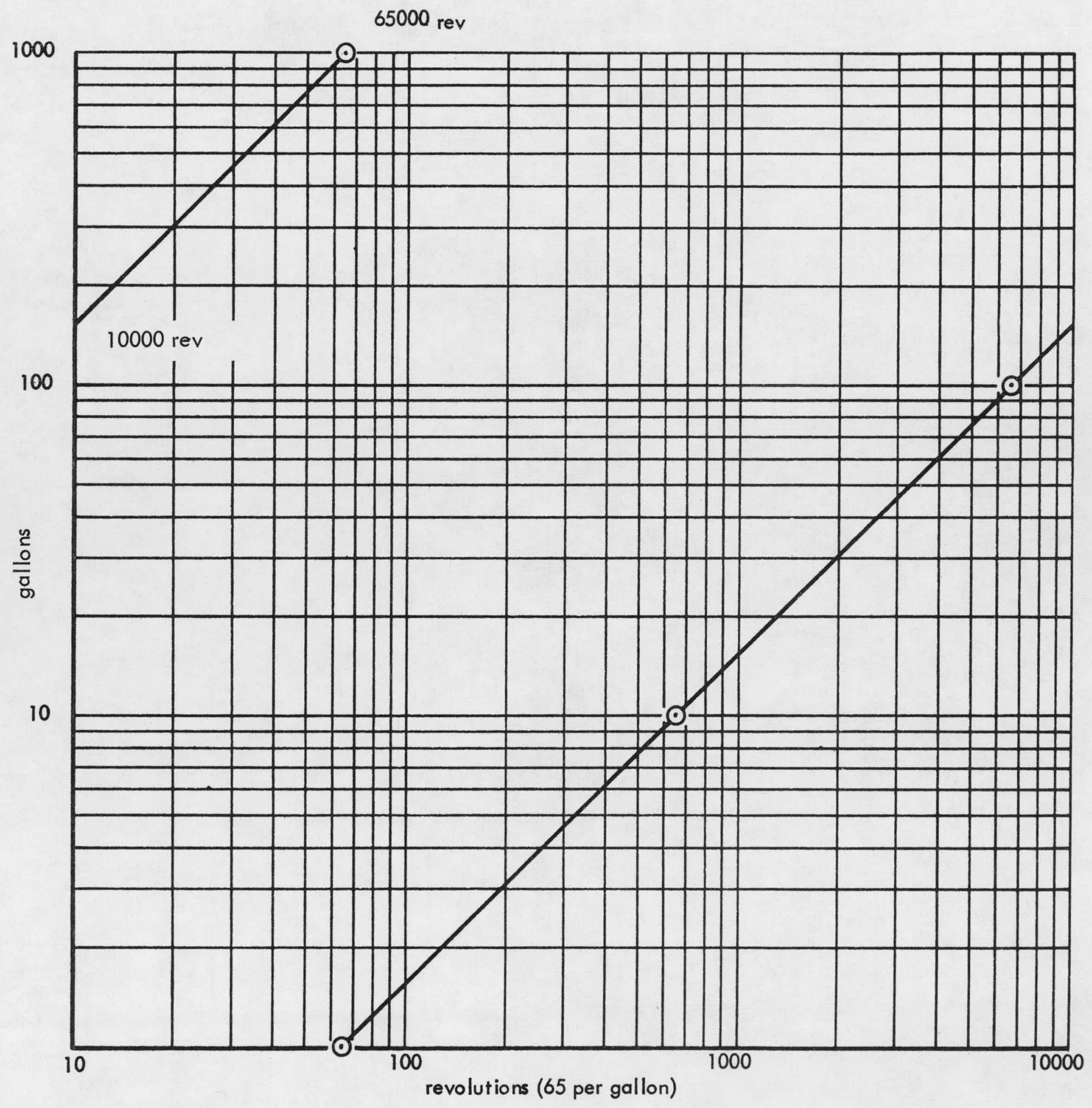


LACBWR Operating Manual

Volume VII, Waste Collection and Treatment

April, 1968

Revised October, 1968

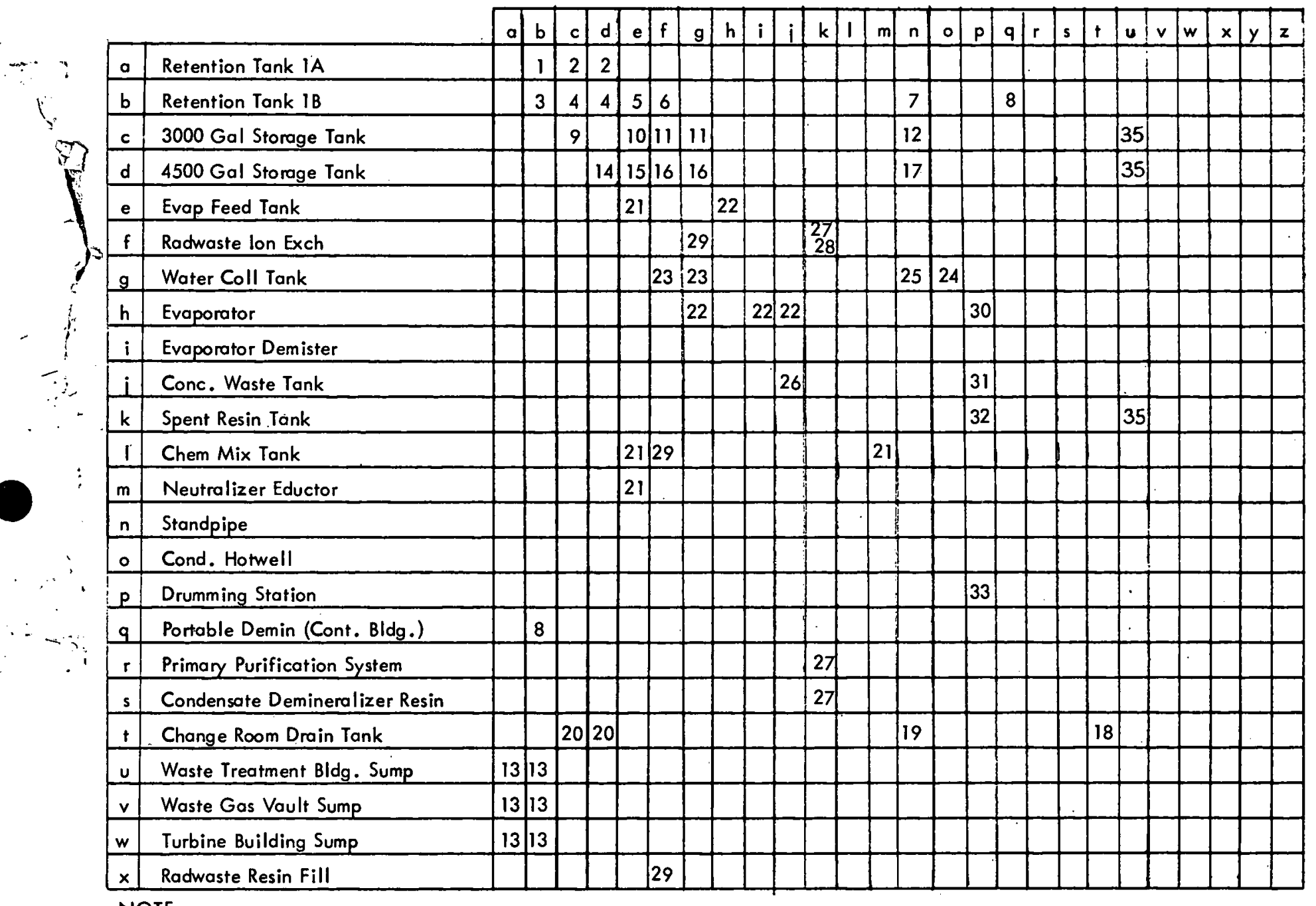

NOTE:

The numbers within the chart refer to procedures. Only the last digit of the procedure number is shown; the prefix 5.4 should be included when referring to any of the procedures. For example, the transfer procedure radwaste ion exch (item f) to water coll tank (item $\mathrm{g}$ ) is shown in the chart as 29. The full numerical designation for chart item 29 is Procedure 5.4.29. 